\title{
A REVIEW OF THE LABORATORY PREPARATION OF PALYNOMORPHS WITH A DESCRIPTION OF AN EFFECTIVE NON-ACID TECHNIQUE
}

\author{
JAMES B. RIDING \& JANE E. KYFFIN-HUGHES \\ British Geological Survey, Keyworth, Nottingham NG12 5GG, UK. jbri@bgs.ac.uk, jeky@bgs.ac.uk
}

\begin{abstract}
The preparation of palynomorphs for microscopy has traditionally used hydrochloric acid $(\mathrm{HCl})$, hydrofluoric acid $(\mathrm{HF})$ and nitric acid $\left(\mathrm{HNO}_{3}\right)$. The use of these acids is both expensive and hazardous. An effective technique of preparation using sodium hexametaphosphate $\left[\left(\mathrm{NaPO}_{3}\right)_{6}\right]$ has been developed. The cleaned, crushed and softened sample is treated with $\left(\mathrm{NaPO}_{3}\right)_{6}$. The deflocculated clay is then sieved away and the residue centrifuged. This method has been successfully tested on seven Jurassic to Quaternary sample sets from the United Kingdom (UK) and Antarctica. In five of these sets, the rock/sediment was prepared using the mineral acid technique and the $\left(\mathrm{NaPO}_{3}\right)_{6}$ procedure. Four of these five sample suites were prepared by both methods quantitatively, so that the concentrations of palynomorphs can be compared. The $\left(\mathrm{NaPO}_{3}\right)_{6}$ method largely proved to be equally as effective as the mineral acid procedure. The Lower Toarcian Whitby Mudstone Formation of Leicestershire and the Middle and Upper Albian Gault Formation of Kent both produced similar palynomorph/kerogen associations. Some differences between the two procedures were, however, noted. The $\left(\mathrm{NaPO}_{3}\right)_{6}$ method produced significantly better results than acid preparations for the uppermost Cretaceous (Maastrichtian) of Antarctica and the Pleistocene Till of northern England. By contrast, the majority of the samples from the in situ late Campanian-early Maastrichtian White Chalk Subgroup of north Norfolk prepared using $\mathrm{HCl}$, were significantly richer in palynomorphs than those treated with $\left(\mathrm{NaPO}_{3}\right)_{6}$
\end{abstract}

Key words: palynology, preparation techniques, Mesozoic, Cenozoic.

RESUMO - A preparação de palinomorfos para microscopia tem usado tradicionalmente os ácidos clorídrico $(\mathrm{HCl})$, fluorídrico $(\mathrm{HF})$ e nítrico $\left(\mathrm{HNO}_{3}\right)$. O uso destes ácidos é, ao mesmo tempo, dispendioso e arriscado. Como alternativa, foi desenvolvida uma técnica eficiente de preparação que utiliza hexametafosfato de sódio $\left[\left(\mathrm{NaPO}_{3}\right)_{6}\right]$. A amostra limpa, fragmentada e finamente britada é tratada com $\left(\mathrm{NaPO}_{3}\right)_{6}$. A argila desfloculada é então tamisada e eliminada e os resíduos centrifugados. Este método foi testado com sucesso em sete amostras do Jurássico ao Quaternário do Reino Unido (UK) e Antártida. Em cinco destas amostras, a rocha/sedimento foi preparada usando a técnica de ácido e a de hexametafosfato de sódio $\left(\mathrm{NaPO}_{3}\right)_{6}$. Quatro destas cinco amostras foram submetidas a tratamentos quantitativos, tanto que se pode comparar as concentrações de palinomorfos. $\mathrm{O}$ método $\left(\mathrm{NaPO}_{3}\right)_{6}$ provou ser tão efetivo quanto o processo de ácido. A Formação Whitby Mudstone, Toarciano inferior de Leicestershire, e a Formação Gault, Albiano médio e superior de Kent, ambas produziram associações similares de palinomorfo/querogênio. Contudo, foram notadas algumas diferenças entre os dois procedimentos. Para o Cretáceo superior (Maastrichtiano) da Antártida e as argilas glaciais do Pleistoceno do nordeste da Inglaterra, o método $\left(\mathrm{NaPO}_{3}\right)_{6}$ produziu resultados significativamente melhores do que as preparações ácidas. Em contraste, a maioria das amostras do Campaniano-Maastrichtiano inferior, provenientes do Subgrupo White Chalk do norte de Norfolk, preparadas com $\mathrm{HCl}$ apresentaram-se mais ricas em palinomorfos do que aquelas tratadas com $\left(\mathrm{NaPO}_{3}\right)_{6}$.

Palavras-chave: palinologia, técnica de preparação, Mesozóico, Cenozóico.

\section{INTRODUCTION}

Palynology is the study of microscopic fossils made of resistant organic material. It was originally known as 'pollen analysis' and encompassed the study of Quaternary pollen grains and plant spores (von Post, 1916). Hyde \& Williams (1944) coined the term palynology to refer to the analysis of all microfossils that are resistant to aggressive chemicals such as hydrochloric acid $(\mathrm{HCl})$ and hydrofluoric acid (HF). Organic-walled microfossils are termed palynomorphs (Tschudy, 1961), and may have plant or animal affinity and may be derived from either the marine or terrestrial realms. They include acritarchs, dinoflagellate cysts, chitinozoa, fungal spores, green/blue algae, plant spores, pollen grains and scolecodonts (Jansonius \& McGregor, 1996a). Palynomorphs, however, do not include organic non- 
microfossil elements such as wood fragments, plant cuticle and amorphous organic material. The generic term for palynomorphs and these other kerogen fragments is phytoclasts (Bostick, 1971).

Palynology is, despite its relative youth as a subdiscipline of geology and palaeontology, a mature subject with an extensive literature. It is used in many integrated geological studies from the Proterozoic to the Holocene for providing detailed biostratigraphical and palaeoecological information. By virtue of their small size, high levels of preservability and hence virtual ubiquity in sedimentary rocks, palynomorphs have been extensively used in the oil and gas exploration and production industry, principally as relative age indices. This economic application has significantly stimulated the study of Phanerozoic palynomorphs and a contemporary overview of this subject has been given by Jansonius \& McGregor (1996b). Ehrenberg (1838) first recorded fossil marine organic microfossils from translucent flakes of flint and chert. The microscopical study of siliceous flakes was continued by palynologists including Wetzel (1933), Deflandre (1936; 1937) and Foucher (1975). Palynomorphs are currently normally extracted from sediments and sedimentary rocks by digestion of the sediment fabric using strong mineral acids. This procedure is both hazardous and expensive, both in terms of chemicals and operator time. The purpose of this contribution is to review palynological processing techniques, including the provision of an extensive bibliography, and to describe, using examples, a new preparation method using a sediment disaggregant that avoids the need to use hazardous chemicals.

\section{THE CHEMICAL NATURE OF PALYNOMORPHS}

Palynomorphs are composed of sporopollenin, a diverse group of highly complex macromolecular biopolymers formed by the oxidative polymerisation of carotenoids and carotenoid esters (Shaw \& Yeadon, 1964; Brooks et al., 1971; Shaw, 1971; Brooks \& Shaw, 1968a,b, 1972, 1978). A generalised chemical formula is $\mathrm{C}_{90} \mathrm{H}_{142} \mathrm{O}_{36}$, but the nature of the molecular structure of sporopollenins is variable (Fawcett et al., 1970). There has been, however, significant progress made recently in regard to the chemical and physical structure of the pollen wall (Rowley, 1976, 1990). Sporopollenin is known to include several unbranched aliphatic chains (Traverse, 1988; Killops \& Killops, 1993); it is closely related to lignin and cutin, is present in certain fungi and algae and modern material, and has a specific gravity of $c .1 .4$ (Flenley, 1971). Juvigné (1973a,b) discovered that the density of sporopollenin increases with time, and quoted values of 1.9 and 2.1 for material from the latest Quaternary (Devensian) and Palaeogene respectively. These specific gravity changes are at least partially related to the effects on sporopollenin of the geothermal gradient in fossil material. Sporopollenin is probably the most resistant organic material of direct biological origin in nature. Manskaya et al. (1973) attributed this robustness to the presence of condensed aromatic structures formed partially from lignin. It is resistant to aggressive mineral acids (e.g. HF) and concentrated alkalis, and can survive heating to $c .300^{\circ} \mathrm{C}$.

The material which forms most geologically-preservable dinoflagellate cysts has been termed dinosporin because it has different fluorescence properties to terrestrially-derived sporopollenin and responds differently to natural and artificial stains such as Bismarck Brown, Fuchsin, Methyl Green or Safranine O (Fensome et al., 1993). Furthermore, Kokinos et al. (1998) found that dinosporin contains a distinctive biomacromolecular material with a largely aromatic structure. These differences are believed to be responsible for the different susceptibilities of dinosporin and sporopollenin to oxidation (see below). Nevertheless, the chemical differences between sporopollenin and dinosporin are believed to be relatively minor, the two substances being part of a closely related complex of organic macromolecules. Dinosporin is thus best regarded as a variety of sporopollenin.

\section{A REVIEW OF THE TRADITIONAL METHODS OF LABORATORY PREPARATION OF PALYNOMORPHS}

The purpose of palynological preparation is to isolate palynomorphs from the rock/sediment matrix, and then to concentrate and present them for study in pristine condition, avoiding any modifications of shape, size and preservation and contamination of the assemblage. This is achieved by using a wide variety of physical and chemical procedures and the precise procedural path is highly variable and dependent upon factors such as lithology, mineralogy, level of induration, organic-richness etc. The tenacious, inert nature of sporopollenin makes palynomorphs geologically preservable in, and extractable from, sediments and sedimentary rocks. To prepare palynomorphs for microscopical study from a sample, the material is traditionally initially treated separately with concentrated $\mathrm{HCl}$ and $\mathrm{HF}$. Important publications describing the traditional palynological preparatory procedure include Norem $(1953,1956)$, Sittler (1955), Staplin et al. (1960), Wilson \& Goodman (1963), Hughes et al. (1964), Lennie (1968), Higgins \& Spinner (1969), Wilson (1971a), Barss \& Williams (1973), Sarjeant (1974, Appendix A), Faegri \& Iversen (1975), Doher (1980), Batten \& Morrison (1983), Herngreen (1983), Evitt (1984), Phipps \& Playford (1984), Johnson \& Fredlund (1985), Farley (1988), Traverse (1988), Litwin \& Traverse (1989), Aldridge (1990), Poulsen et al. (1990), Moore et al. (1991) and Batten (1999). Two of the most recent and comprehensive accounts of this topic were given by Wood et al. (1996) and Green (2001, chapters 25 and 26). Wood et al. (1996) is a review of modern palynological preparatory techniques and part of a comprehensive, multiauthored textbook on palynology (Jansonius \& McGregor, 1996a). The accounts by Green (2001) are two chapters from a modern and comprehensive textbook on palaeontological techniques and give step-by-step 
instructions on all established palynological preparation methods. There is an extensive literature on palynological techniques; in particular, many contributions on this topic were published in the journal Micropaleontology during the 1960s. The references in this paper are deemed to be the principal contributions on this subject, but it should not be considered to be a fully comprehensive bibliography.

Normally around 20-30 g of unweathered sample material are required for a successful palynological preparation. Larger amounts of organic-lean sediment per sample are needed due to the low density of sedimentary organic material in, for example, some pure limestones (Wilson, 1971a; Nørgaard et al., 1991) and sand-rich sedimentary rocks. Clean sampling equipment is imperative in order to protect against the cross contamination of palynomorphs between samples. Funkhouser (1967) gave a brief description of sample types and possible sources of contamination during sampling and allochthonous palynomorphs. Contamination may be from diverse sources, such as drilling mud additives (Traverse $e t$ al., 1961), laboratory supplies (Fisher, 1962) and even blackboard chalk (Echols \& Levin, 1964). A comprehensive and up-to-date description of field collecting procedures, laboratory documentation, curation and related issues was given by Green (2001). Wood \& Segroves (1963) briefly described a method for the standardisation of palynological sample collection.

The use of HF in palynological preparation was introduced by Assarson \& Granlund (1924). In sediments and sedimentary rocks other than peat/coal, the $\mathrm{HCl}$ and HF remove carbonate and silicate minerals respectively, thereby destroying the matrix of the rock and leaving a residue of organic material and resistant minerals (e.g. rutile and tourmaline). The $\mathrm{HCl}$ treatment is always performed first and the decalcified residue must be decanted to neutrality before adding HF. This is to remove all calcium ions, which would form calcium fluoride $\left(\mathrm{CaF}_{2}\right)$ on reaction with the HF. Calcium fluoride is relatively insoluble and hence difficult to remove from the residue. Glass should not be used for HF treatment because this acid rapidly corrodes glass (Cridland, 1966). The mineral acids have no significant corrosive effect on sporopollenins and other organic elements such as wood fragments and effectively etch the palynomorphs from the rock fabric. Sarmiento (1957) used orthophosphoric acid $\left(\mathrm{H}_{3} \mathrm{PO}_{3}\right)$ to remove carbonates and claimed that it is a gentler reagent than $\mathrm{HCl}$. Despite this, $\mathrm{H}_{3} \mathrm{PO}_{3}$ has not replaced $\mathrm{HCl}$ for carbonate mineral dissolution in most palynology laboratories. Following mineral acid treatment, the palynomorphs in the raw organic/mineral residue are separated and concentrated in various ways. These include briefly oxidising, normally with nitric acid $\left(\mathrm{HNO}_{3}\right)$, to clear the residue of any residual fine organic materials (Funkhouser \& Evitt, 1959). Other methods of 'cleaning' the palynomorphs include ultrasonic treatment, the density separation of any resistant minerals and the sieving away of finely disseminated organic matter (Caratini, 1980; Ediger, 1986). Density separation techniques normally involve either centrifuging or 'swirling' in a large watch glass the residue in order to separate the dense mineral fraction from the light organic residue. Centrifuging media are heavy liquids such as bromoform $\left(\mathrm{CHBr}_{3}\right)$, sodium polytungstate $\left(3 \mathrm{Na}_{2} \mathrm{WO}_{4} 9 \mathrm{WO}_{3} \mathrm{H}_{2} \mathrm{O}\right)$, stannic chloride $\left(\mathrm{SnCl}_{4}\right)$, zinc bromide $\left(\mathrm{ZnBr}_{2}\right)$, and zinc chloride $\left(\mathrm{ZnCl}_{2}\right)$ (Davis, 1961; Kummel \& Raup, 1965; Munsterman \& Kerstholt, 1996). Forster \& Flenley (1993) developed a density gradient centrifugation technique that removes extraneous organic materials and can fractionate modern and fossil palynomorphs. Tschudy (1960) devised a device termed a 'Vibraflute' to separate palynomorphs from mineral grains and finely disseminated organic material. The 'Vibraflute' is a subhorizontal glass tube, which is connected to a vibrotool (Tschudy, 1960, fig.1). A sample residue is placed in the glass tube and the tube is agitated with the vibrotool. The palynomorphs tend to concentrate in the centre of the glass tube, with the resistant minerals and fine material at the proximal and distal ends respectively; these three fractions can then be readily separated. Another method of separating palynomorphs from extraneous organic material was described by Hansen \& Gudmundsson (1979). Following standard acid preparation, oxidation, filtration and centrifugation, these authors treated acidresistant residues with ethyl alcohol $\left(\mathrm{C}_{2} \mathrm{H}_{5} \mathrm{OH}\right)$, which is absorbed into the cavities of the palynomorphs thereby reducing their density. The denser, massive organic material (e.g. wood fragments, resistant minerals etc.) then settles out in a separation tube (Hansen \& Gudmundsson, 1979, fig. 2), whereas the less dense palynomorphs are in suspension close to the alcohol/water interface and can be separated by decanting. This method is especially useful in highly carbonised material or rocks with low palynomorph contents. Palynomorphs can also be separated from aqueous residues by flotation using either solvents of high specific gravity or oil (Kurtz \& Turner, 1957; Urban, 1961). Bond (1964) described a simple method for the removal of light colloidal material from palynological preparations. Colloidal material may also be removed by a combined $\mathrm{ZnBr}_{2}$ and HF method according to Björck et al. (1978). Residues are also normally treated with a dilute alkali solution such as ammonium hydroxide $\left(\mathrm{NH}_{4} \mathrm{OH}\right)$ or potassium hydroxide $(\mathrm{KOH})$ in order to neutralise any humic acids present; these may be released during the oxidation process (see below). If the palynomorphs and the remaining kerogen macerals form clumps at this stage, these aggregations may be dispersed by brief ( $<1$ minute) ultrasonic vibration, at $c .50$ $\mathrm{kHz}$, of the residue. At this stage, if the palynomorphs are pale or have been bleached during the preparation process, they may be stained to accentuate their body colour to aid observation and make any photomicrography easier. Several staining media can be used, for example Bismarck Brown, Congo Red, Fuchsin, Methyl Green, Methylene Blue, Safranine O, Vert Green and various food colouring products (Artusy \& Artusy, 1956; Clarke, 1963; Wilson \& Goodman, 1963).

Following these various cleaning procedures, the aqueous palynomorph-rich residue is then concentrated by 
sieving to the required level (Kidson \& Williams, 1969; Raine \& Tremain, 1992) and mounted on glass microscope slides. Vidal (1988) described the use of a membrane-filtering unit for maximising palynological yield in organic-lean material. Slide production is commenced by evaporating several droplets of residue onto a glass coverslip. The residue to be mounted is treated with a dispersing agent in order to form a thin film on the coverslip with an even distribution of grains (Jeffords \& Jones, 1959). When dry, the coverslip is mounted to the microscope slide using a proprietary mounting medium. Schopf (1960) described a double coverslip technique. Various mounting media have been used and include Canada balsam, Cellosize, Clearcol, Elvacite, gelatin, glycerine, glycerine jelly, gum arabic, silicone oil, Vinylite and various optical adhesives (Andersen, 1960; Wilson, 1968; Barss \& Crilley, 1976). No single mountant is unequivocally superior and these vary in optical properties, principally the refractive index, and longevity. If the mounting medium is alcohol-based, palynomorphs may be isolated for scanning electron microscope (SEM) study by using a solvent such as dimethyl sulphoxide $\left(\mathrm{C}_{2} \mathrm{H}_{8} \mathrm{OS} /\left(\mathrm{CH}_{3}\right)_{2} \mathrm{SO}\right.$, also referred to as 'DMSO') (Shane \& Clark, 1981). Jacobsen \& Schopf (1979) described a methodology for the reverse process, i.e. mounting on glass slides specimens that have been studied using an SEM. Palynomorphs mounted in glycerine jelly may also be extracted and remounted/reused (Wilson, 1971b). It should be noted that the body colour of palynomorphs mounted on microscope slides frequently fade with time. Riding \& Helby (2001, fig. 16) demonstrated that specimens of the Jurassic dinoflagellate cyst Tabularium senarium have faded significantly over a $c$. 20-year period. This phenomenon is especially noticeable in Tabularium senarium because this species is characterized by prominent, dark, low relief intratabular ornamentation, however fading has been discerned in many other palynomorph taxa. The remainder of the aqueous residue is normally stored as a liquid and some laboratories favour the addition of several drops of dilute $\mathrm{HCl}$ or phenol $\left(\mathrm{C}_{6} \mathrm{H}_{6} \mathrm{O}\right)$ to prevent fungal infestation (Elsik, 1966a). Dempsey \& Urban (1965) and Felix \& Burbridge (1985) described methods for the dry storage of palynomorph residues. It is necessary to ensure that all laboratory equipment used in this process is scrupulously clean at the start of this procedure. This is to avoid the cross contamination of samples via residues from previous samples on acid vessels and other laboratory equipment. Some laboratories use a dishwasher with strong detergents, disposable labware or a powerful chemical cleaning agent such as chromic acid $\left(\mathrm{CrO}_{3}\right)$, which cleans palynomorphs and organic materials by oxidation.

Megaspores may require alternative preparatory techniques (Hills \& Sweet, 1972). Furthermore, it should be noted that coal samples, which lack silicate minerals, are prepared by oxidation with Schulze's solution or fuming $\mathrm{HNO}_{3}$. There is the 'dry' (or 'Raistrick') method (Raistrick \& Simpson, 1933; Raistrick, 1934; Raistrick \& Marshall, 1939) and the so-called 'wet' method (Smith \& Butterworth, 1967). Schulze's solution is an extremely powerful oxidising agent and comprises $70 \% \mathrm{HNO}_{3}$ supersaturated with potassium chlorate $\left(\mathrm{KClO}_{3}\right)$ (Manum, 1956; Staplin et al., 1960; Traverse, 1988). Staplin et al. (1960) described how pretreatment of coals with acetone $\left(\mathrm{CH}_{3} \mathrm{COCH}_{3}\right)$, benzene $\left(\mathrm{C}_{6} \mathrm{H}_{6}\right)$ and methanol $\left(\mathrm{CH}_{3} \mathrm{OH}\right)$ may shorten the oxidative process of coals. In the 'dry' method, the coal is crushed and Schulze's solution is added carefully. A variant of this technique is that nitric acid is added to a mixture of coal and $\mathrm{KClO}_{3}$. Following the oxidation process, which varies considerably depending upon the coal being prepared, the Schulze's solution is washed away by repeated decantations and dilute alkali is washed through the residue. The sporerich residues can then be concentrated and mounted on microscope slides. Smith \& Butterworth (1967, p. 100-104) fully described the 'wet' method and various other techniques applicable to coal samples. More information on coal preparations can be found in Tschudy (1958), Staplin et al. (1960), Spielholtz et al. (1962), Lee (1964), Gray (1965a,b) and Wood et al. (1996). Likewise, peat samples are prepared by treatment in hot $10 \% \mathrm{KOH}$, washing and acetolysis using acetic anhydride $\left[\left(\mathrm{CH}_{3} \mathrm{CO}\right)_{2} \mathrm{O}\right]$ and concentrated sulphuric acid $\left(\mathrm{H}_{2} \mathrm{SO}_{4}\right)$ in a 9:1 ratio (Brown, 1960; Erdtman, 1960; Bigelow, 1980; Moore et al., 1991; Green, 2001, p. 132, 133). Acetolysis, or acetylisation, is often mis-termed acetylation but is in fact a two-step process involving both acid hydrolysis and esterification (Erdtman, 1960). Acetolysis was discovered by Erdtman (1936) and eliminates or reduces cellulose from organic residues. The reaction is exothermic and water should not be added to the solution. Marret (1993) reported that acetolysis selectively destroys Quaternary dinoflagellate cysts. Specifically, this treatment was proved to adversely affect protoperidiniacean forms, whereas gonyaulacacean taxa are only slightly sensitive to acetolysis (see below). Occasionally, the need may arise to analyse solid bituminous materials and Faruqi \& Copley (1966) described a technique for the extraction of palynomorphs from tar.

This brief summary gives the basic procedures to a highly complex, and potentially relatively slow, procedure that relies considerably on operator experience and sound laboratory technique, in addition to the availability of a well-appointed facilities (Wrenn, 1998).

\section{ASPECTS OF THE SUSCEPTIBILITY OF PALYNOMORPHS TO OXIDATION}

Despite their great physio-chemical robustness, palynomorphs are susceptible to oxidation, both of a sustained and rapid nature (Havinga, 1964, 1967; Kedves, 1985; Campbell, 1991; Campbell \& Campbell, 1994). Oxidising reagents break up carbon chains in organic substances, forming simpler carbon compounds in a stepwise fashion (Holst, 1954). Exposed sedimentary rocks have been subjected to constant oxidation during the weathering process and the weathered crust should be thoroughly removed from an outcrop before sampling for palynology. The destruction of sedimentary organic material by 
weathering is significantly greater in hot climates. Similarly, great care should be taken when treating organic residues with oxidising agents in the laboratory during the later stages of preparation. It is recommended that sample residues should be carefully monitored for palynomorph damage during the oxidising process. Chemicals such as $\mathrm{HNO}_{3}$ and hydrogen peroxide $\left(\mathrm{H}_{2} \mathrm{O}_{2}\right)$ are powerful oxidising agents and can destroy palynomorphs (Hopkins \& McCarthy, 2002). This destruction can be either complete or partial degradation; for example $\operatorname{Kempf}$ (1971, pl. 23) demonstrated that $\mathrm{H}_{2} \mathrm{O}_{2}$ preferentially destroys the innermost layer of water-fern (Salvinia) megaspores by oxidation. More recently, Traverse (1990) demonstrated that hollyhock (Althea rosea) pollen is fundamentally altered by brief treatment with 'Clorox', a commercial bleaching agent that uses sodium hypochlorite $(\mathrm{NaOCl})$ as the active ingredient. The outermost layer of the exine including the prominent, abundant spines is destroyed and the remaining exine shrinks and collapses. Other studies of the selective degradation of palynomorphs include Downie (1959), Elsik (1966b) and Schrank (1988). Certain palynomorphs have different tolerances to chemical oxidation. For example, Quaternary heterotrophic protoperidiniacean dinoflagellate cysts, such as Brigantedinium, are much more susceptible than autotrophic gonyaulacacean genera (e.g. Impagidinium, Operculodinium and Spiniferites) to oxygen-related decay (Dale, 1976; Wall et al., 1977; Marret, 1993; Head, 1996; Zonneveld et al., 1997, 2001). Savrda et al. (2001), in an elegant study, related this factor to ichnology and sedimentology. These authors studied the Quaternary of the New Jersey slope, eastern USA and found low gonyaulacacean:peridiniacean dinoflagellate cyst (G:P) ratios in rapidly deposited clays with low bioturbation. By contrast, Savrda et al. (2001) recorded associations rich in gonyaulacacean cysts from intensely bioturbated, sand-rich sediments. These differences were interpreted as taphonomic, rather than reflecting the original dinoflagellate cyst assemblages. Clearly the majority of the protoperidiniacean forms in the burrowed, sandy sediments had been oxidised in situ (McCarthy et al., 2002). Hopkins \& McCarthy (2002) also noted the selective destruction of protoperidiniacean dinoflagellate cysts in the Quaternary of offshore New Jersey using $\mathrm{H}_{2} \mathrm{O}_{2}$. These authors also found that the adverse effects of $\mathrm{H}_{2} \mathrm{O}_{2}$ on pollen and spore floras were significantly less than on dinoflagellate cysts. Hopkins \& McCarthy (2002) stressed that, rather than being a barrier to palaeoecological interpretations, a thorough knowledge of the differential preservation of palynomorphs can help the elucidation of geological problems. By contrast with the Quaternary, Dodsworth (1995) found that, in the laminated calcareous shales of the Mid Cretaceous Greenhorn Formation of Colorado, USA, oxidation with Schulze's solution and $\mathrm{KOH}$ solution selectively destroyed gonyaulacacean dinoflagellate cysts and did not affect peridiniacean taxa.

In certain cases, where sedimentary rocks contain significant levels of amorphous organic material, however, strong oxidising reagents may have to be used in the preparation process. This is because amorphogen tends to surround palynomorphs, thereby occluding them for microscopical study (Funkhouser \& Evitt, 1959). In these cases, the risk of palynomorph damage or loss via oxidation is balanced by the need for their efficient extraction. Normally a swift $(<5$ minutes) treatment of the sample residue with $\mathrm{HNO}_{3}$ or fuming $\mathrm{HNO}_{3}$ in a Buchner Flask is all that is required (Sarjeant, 1974, fig. 45). After oxidation, the residue should be washed with a dilute alkali such as $10 \%$ $\mathrm{KOH}$ or $5 \% \mathrm{NH}_{4} \mathrm{OH}$; this clears away any humic acids which have been produced by the oxidising agents. The alkali treatment also helps to swell the palynomorphs, which may have shrunk during oxidation. Two Jurassic examples of organic-rich lithologies that require severe oxidation are the widespread organic-rich Lower Toarcian mudstones deposited during the Oceanic Anoxic Event (OAE) (Bucefalo Palliani et al., 2002) and the Upper Jurassic Kimmeridge Clay Formation (Ioannides et al., 1976, 1988; Nøhr-Hansen, 1986; Riding \& Thomas, 1988). In these cases, the organic residues are typically treated for sustained periods with aggressive oxidising agents such as fuming $\mathrm{HNO}_{3}$ or Schulze's solution in order to dissolve and fragment the sapropelic material so that it can be sieved away (Neves \& Dale, 1963). Ultrasonic treatment can also help to fragment the amorphogen (Funkhouser \& Evitt, 1959), but care must be taken as this technique can damage palynomorphs, especially if they are carbonised and therefore brittle (McIntyre \& Norris, 1964). If an organicrich sedimentary rock has been deeply buried, the amorphous organic material becomes much more tenacious and resistant to oxidation. An example of this is the Upper Jurassic (Oxfordian to Volgian) Brae Formation (Humber Goup) of the northern North Sea (Riley et al., 1989; Richards et al., 1993). Typically, Brae Formation material requires extended (> 24 hours) oxidation with Schulze's solution in order to release palynomorphs. This heavily oxidised material is frequently bleached of body colour and requires staining, to increase contrast, prior to microscopy. Experience of the laboratory preparation of these Jurassic organic-rich sediments indicates that the judicious use of strong oxidising agents does not significantly affect the palynomorph associations detrimentally. Part of the reason for this may be that Jurassic dinoflagellate cyst assemblages are dominated by gonyaulacacean taxa (Riding \& Ioannides, 1996). Highly carbonised palynomorphs may be lightened to facilitate study by using Schulze's solution. However, this treatment may degrade them and the palynomorphs often redarken (Marshall, 1980). Safer methods of removing amorphous organic material have been described for preQuaternary material. For example, Eshet \& Hoek (1996) worked on a Late Cretaceous (Campanian-Maastrichtian) limesone/marl succession from southern Israel, which is extremely rich in amorphous organic material. These authors bleached the residues with $\mathrm{NaOCl}$ for 8-12 hours and found that this treatment released abundant and well-preserved dinoflagellate cyst assemblages (see also Hoffmeister, 1960). 


\section{DISADVANTAGES OF THE ACID-DIGESTION PALYNOLOGICAL PREPARATION METHOD}

The use of mineral acids in palynological preparation is highly expensive in terms of the cost of raw materials, laboratory infrastructure and staff time. Due to the aggressively corrosive nature of concentrated $\mathrm{HCl}, \mathrm{HF}$ and $\mathrm{HNO}_{3}$, these reagents must be used in modern, well-maintained fume cupboards, operatives should wear good quality protective clothing/footwear and all liquid acidic waste should be neutralised prior to disposal (Costa, 1983; Wood et al., 1996; Green, 2001). Hydrofluoric acid is the most hazardous chemical used in traditional palynological processing (see below). Safer methodologies such as the 'macerationtank-method' of Poulsen et al. (1990) have been developed for the use of HF. The advantage of this method is that both fresh and waste HF is carried along tubing and is never used in an open vessel. Another closed system technique is to adapt a kidney dialysis unit for HF macerations (Jackson et al., 1974; McKee, 1977). Certain legislations require the gases emanating from fume cupboards to be made safe ('scrubbed'), rather than merely venting them to the atmosphere. Specifically, the United Kingdom (UK) government passed the Control of Substances Hazardous to Health (COSHH) Regulations in 1988. These regulations have since been updated (Health and Safety Executive, 1999; or go to: http://www.hse.gov.uk/ hthdir/noframes/coshh/). The COSHH regulations stipulate that, if a hazardous chemical is used in the workplace, a safer alternative must be used if possible. If this is not viable, the minimum amount of the hazardous substance must be used. Most other developed countries have similar legislation. The regulations pertaining to mineral acids by health and safety/environmental protection legislation also imposes administrative and logistical burdens on palynological laboratory facilities. For example in the USA, the maintenance costs of a pre-treatment system for acid waste disposal, plus licensing for use of these chemicals, varies from state to state and can be as much as $\$ 50,000$ per year above normal building maintenance costs. These costs and logistical overheads also apply to modern closed vessel technologies such as microwave digestion systems (Ellin \& McLean, 1994; Jones, 1994, 1998; Jones \& Ellin, 1998; Simes \& Wrenn, 1998). The difficulties associated with the use of mineral acids are exacerbated in mobile laboratories such as those used on offshore oilfield drilling rigs. In particular, Health and Safety issues regarding hazardous chemicals are significantly more acute in offshore settings where the risks of accidental spillage are much higher. Operators are, in the main, willing to invest in the relatively expensive rig laboratory infrastructure because many offshore drilling installations now require precise and rapid biostratigraphical data aquired during drilling operations (Payne et al., 1999). This is largely because modern directional drilling techniques can drill along relatively thin oil/gas reservoir beds. To maximise production levels, the drill bit must stay in the pay horizon. Any deviations from this path are detected by using palynological and/or micropalaeontological analyses of the cuttings/core material by microscopists at the rigsite (Holmes, 1999; Shipp, 1999).

\section{THE HEALTH HAZARDS OF HYDROFLUORIC ACID}

Hydrofluoric acid is by far the most hazardous and corrosive chemical used in the traditional palynological preparatory process. Its unique properties, which make HF so useful in surface cleaning and etching in addition to mineral digestion, also make it significantly more hazardous than either $\mathrm{HCl}$ or $\mathrm{HNO}_{3}$. For example $\mathrm{HF}$ is 1000 times more undissociated than $\mathrm{HCl}$ and furthermore it is highly lipid soluble. Hydrofluoric acid causes severe burns and may be fatal if it comes into contact with $c .5 \%$ of the body area. At low levels of exposure and/or concentrations, the initial contact burns from hydrogen ions play only a minor role in HF injuries; this is unlike other acids. Upon contact there is a delay, after which the HF disassociates via ionisation into hydrogen and fluoride radicals; it is the fluoride ions that cause the principal tissue and bone damage. This is the most insidious aspect of $\mathrm{HF}$, such that, if it contacts the skin, pain is not generally felt immediately. Because it is highly lipid soluble, it penetrates the skin rapidly and, upon ionisation, fluoride ions rapidly cause prolonged destruction of deep soft tissues and bone. The fluoride ions typically initially destroy soft tissue via liquefaction necrosis and when bones are reached they are rapidly decalcified (Hodgkinson, 1991). Bone decalcification may also cause systemic fluoride poisoning in extreme cases; this condition is termed fluorosis and symptoms include weight loss, brittle bones, and anaemia. Because of the rapidity with which HF penetrates animal tissue, it is extremely difficult to neutralise and the destructive effects may last several days (Head, 1995a,b). In the gaseous phase, HF is extremely irritating to the eyes, skin and respiratory system. Airbourne concentrations of HF of $10-15$ ppm will cause irritation and levels above $30 \mathrm{ppm}$ are deemed to be extremely hazardous to life and health.

Any contact of HF with skin should be liberally irrigated with cold water and then treated with calcium gluconate $\left[\left(\mathrm{HOCH}_{2}(\mathrm{CHOH})_{4} \mathrm{COO}\right)_{2} \mathrm{Ca}\right]$ gel before urgently seeking immediate medical treatment. This substance comprises a mixture of calcium gluconate in a water-soluble gel medium, and can also be injected subcutaneously in extreme cases. Note that this gel should not be applied to eyes that, if affected, should be irrigated then treated with $1 \%$ calcium gluconate drops every few hours for several days. Calcium gluconate is an efficacious HF antidiote because it combines with the $\mathrm{HF}$ to form insoluble $\mathrm{CaF}_{2}$, thereby preventing extraction of calcium from tissues and bones and the resulting painful, slow-healing burns. Calcium gluconate gel should ideally be stored in a refrigerator, however even when it is chilled it has a limited shelf life, normally of approximately 2 years. Because of the ability of HF to cause delayed tissue/ bone damage without immediate pain, all incidents of skin, eye or tissue contact with this substance should receive 
immediate first aid and medical evaluation, even if the areas of contact appear normal and no discomfort is felt.

The above description of the hazardous nature of HF should not preclude its laboratory use. With well-appointed laboratory facilities, suitable protective clothing/equipment and adequate training, it may be safely used in palynological preparation (see Green, 2001, chapters 8,9). Given the extreme toxicity of this substance, it is a testament to the sustained skill and good practice of palynological technicians worldwide that relatively few HF-related accidents have occurred in preparation laboratories since its introduction by Assarson \& Granlund (1924).

\section{PREVIOUS LITERATURE ON PALYNOLOGICAL PREPARATION WITHOUT THE USE OF MINERAL ACIDS}

It is clear that if palynomorphs could be extracted from sediments and sedimentary rocks without the use of mineral acids, this process would be safer, cheaper and probably quicker. Despite some mention of palynological preparation techniques which do not involve mineral acids in the literature, there is no widely practiced non-acid method currently in use. This section is a review of this subject in the literature.

Knox (1942) described a simple method of the separation

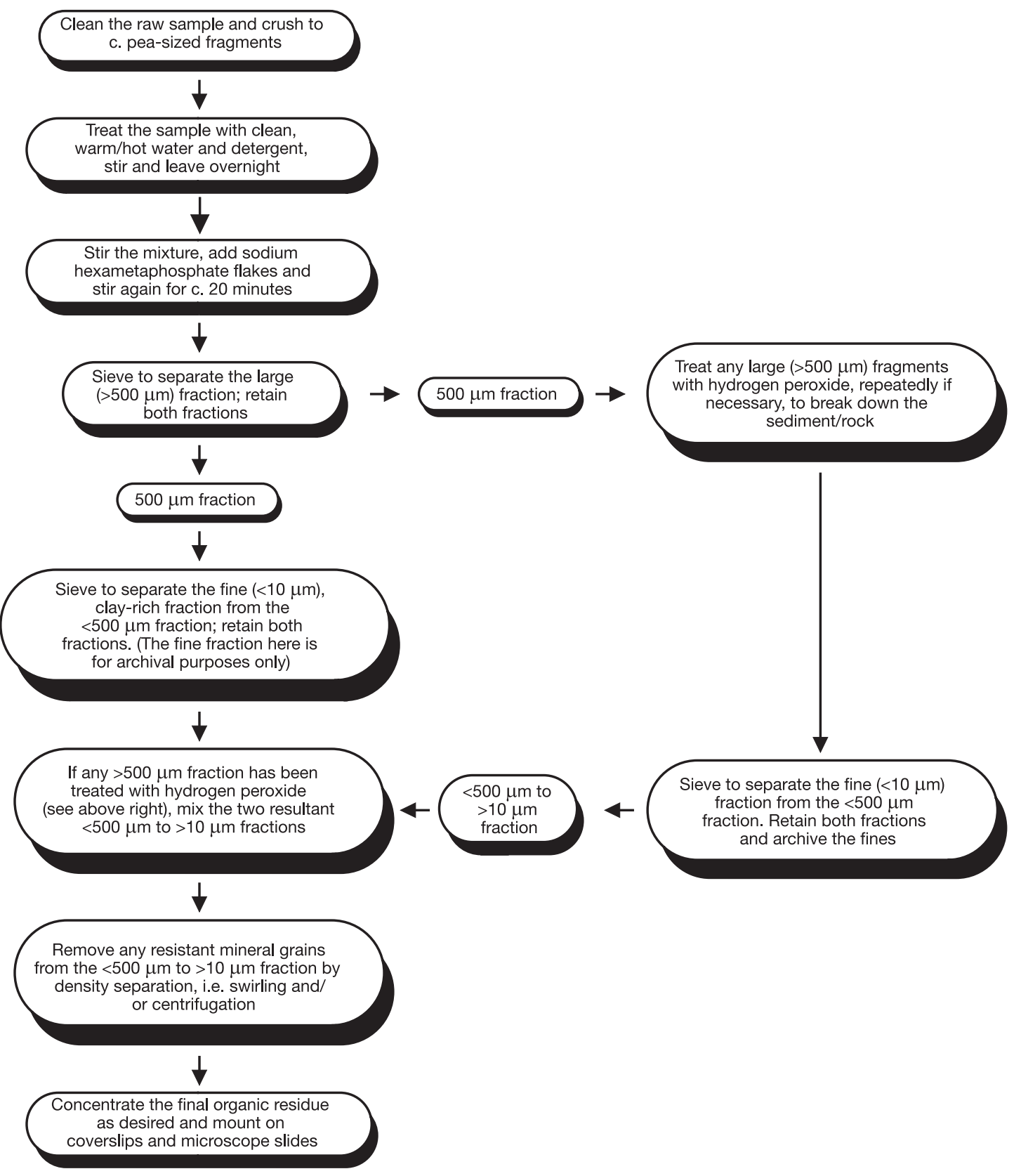

Figure 1. A flow chart illustrating the principal steps in the palynological preparation procedure using sodium hexametaphosphate. 
of palynomorphs by a centrifugation technique. Firstly, the sediment is deflocculated by agitating it with $\mathrm{CH}_{3} \mathrm{COCH}_{3}$, $\mathrm{CHBr}_{3}$ or water. This is especially suitable for unconsolidated or lightly lithified rocks. If the sedimentary rock is highly indurated, acids may be required to break the rock fabric down. Following deflocculation, the sediment is washed, dried and treated with a mixture of $\mathrm{CH}_{3} \mathrm{COCH}_{3}$ and $\mathrm{CHBr}_{3}$ with a specific gravity of 2.3. It is then centrifuged and the sediment may require several centrifugations. The light fraction, containing the palynomorphs, floats on the surface of the heavy liquid after centrifugation and can be easily separated from the denser components.

A novel method of concentrating palynomorphs from unconsolidated sediments from semi-arid regions was described by Arms (1960). This author found that palynomorphs in material from the south-west of the USA and Mexico formed an insoluble colloid when treated with HF. To avoid this situation, the sample is placed in a $50 \mathrm{~cm}^{3}$ centrifuge tube which is in turn placed in a 1 litre beaker (Arms, 1960, fig. 1). Distilled water is added to the sample, which is then treated with a 5\% solution of water soluble depressant, $5 \%$ solution of pine oil in distilled water which has been agitated and laboratory detergent solution. Then gas is bubbled slowly through the aqueous mixture for 15 minutes. Bubbles will emerge from the centrifuge tube and these should be collected in the beaker. Mineral material, including mineralised microfossils, will remain in the tube and the bubble residue in the beaker should be rich in palynomorphs. This palynomorph-rich residue should be centrifuged if necessary and slides made up as normal. The depressant retards the removal of silicates in the bubbles, the pine oil solution adjusts the surface tension and coats the grains and the detergent produces the bubbles.

Brown (1960) described a modification for palynology of the disaggregation method used by Frizzel \& Middour (1951), for the isolation of radiolaria using sodium pyrophosphate $\left(\mathrm{Na}_{4} \mathrm{O}_{7} \mathrm{P}_{2}\right)$. This chemical was found to disaggregate clays, although Brown (1960, p. 40-41) reported that it may destroy palynomorphs by oxidation, especially if heated. Shales do not consistently disaggregate when treated with $\mathrm{Na}_{4} \mathrm{O}_{7} \mathrm{P}_{2}$. The disaggregation of some relatively tenacious mudrocks using $\mathrm{Na}_{4} \mathrm{O}_{7} \mathrm{P}_{2}$ can be accelerated by boiling, however this has the effect of destroying the organic material, including palynomorphs, by oxidation according to Brown (1960, p. 9495). Bates et al. (1978), however, stated that $\mathrm{Na}_{4} \mathrm{O}_{7} \mathrm{P}_{2}$ does not cause the oxidation of palynomorphs. These authors described a method of preparing clay-rich Quaternary samples using $\mathrm{Na}_{4} \mathrm{O}_{7} \mathrm{P}_{2}$. This method used the $\mathrm{Na}_{4} \mathrm{O}_{7} \mathrm{P}_{2}$ as a clay deflocculant after the sample has been treated with either $\mathrm{HCl}$ or sodium hydroxide $(\mathrm{NaOH})$. Following removal of the clay, samples were then still treated with HF (Bates et al., 1978, p. 460). Cwynar et al. (1979) described a sieving procedure for concentrating Quaternary pollen following both acid and $\mathrm{Na}_{4} \mathrm{O}_{7} \mathrm{P}_{2}$ preparation procedures.

A procedure for the physical disaggregation of unconsolidated samples was described by Staplin et al. (1960). The fragmented and dried sample is treated with a mixture of proprietary core analysis fluid ('Soltrol C') and a miscible liquid detergent. Addition of a 1:1 $\mathrm{CH}_{3} \mathrm{COCH}_{3}$ and $\mathrm{C}_{6} \mathrm{H}_{6}$ mixture may help in some cases. This sample mixture is left to disaggregate and agitation is helpful. After settling, the clear liquor is decanted, boiling water added and the mixture stirred. It is then washed and centrifuged. This technique was envisaged as being a precursor to the acid phase of the traditional technique, but Staplin et al. (1960) stated that in rare cases the sample may have broken down such that further chemical treatment is superfluous. Even if the sample requires acid treatment following this disaggregation, Staplin et al. (1960) claimed that the pre-treatment saves both time and reagents.

Eagar \& Sarjeant (1963) briefly described a technique used to extract dinoflagellate cysts from the London Clay Formation (Eocene) of southern England using a modification of the standard calcareous microfossil preparation procedure. The clay samples are soaked in water and sieved using a $64 \mu \mathrm{m}$ sieve in order to remove the fine clay fraction. The $>64 \mu \mathrm{m}$ fraction is then boiled with sodium carbonate $\left(\mathrm{Na}_{2} \mathrm{CO}_{3}\right)$ in order to deflocculate the remaining clay and re-sieved. This procedure is repeated as necessary until the clay fraction has all been removed, leaving a clean, palynomorph-rich, residue. Eagar \& Sarjeant (1963) commented that the dinoflagellate cyst assemblages obtained using this method are entirely composed of large chorate (spine-bearing) forms. It is probable that many of the smaller forms were washed away during the sieving process.

One of the most comprehensively described non-acid techniques is the mechanical disaggregation method of Felix (1963). Samples of Palaeogene/Neogene shales from the Gulf Coast, USA gave unsatisfactory results when prepared using the traditional preparation procedure. Firstly, the sample is washed for 24 hours in distilled water using a rotary washer. More indurated lithologies may require a 48 hour washing phase and, in some cases, the addition of a water-softening agent. The disaggregated sample is then centrifuged and the organic fraction dried and powdered. The powder is treated with $\mathrm{CHBr}_{3}$ and toluene $\left(\mathrm{C}_{7} \mathrm{H}_{8}\right)$, followed by gentle agitation in a microblender for 15 minutes. This allows the palynomorphs and kerogen to float, thereby allowing easy separation from the denser mineral fraction.

Williams \& Downie (1966a, p. 20) briefly mentioned the occurrences of dinoflagellate cysts in washed preparations for foraminifera from the London Clay Formation of Isleworth, Middlesex. Murray J. Hughes, a micropalaeontologist with the British Geological Survey (BGS), had noted large clumps of abundant dinoflagellate cysts in disaggregated London Clay Formation samples and sent some picked specimens for identification to Charles Downie at the University of Sheffield in 1958. These samples had been prepared using standard, non-destructive methods for extracting calcareous microfossils (see also Eagar \& Sarjeant, 1963). This action led directly to the intensive study of the marine palynology of the Palaeogene of southern England using traditional preparation techniques by Charles Downie and co-workers at Sheffield (e.g. Williams \& Downie, 1966b,c; Eaton, 1976; Bujak et al., 1980). 
Traverse (1978, p. 993) briefly described an impromptu method of palynological preparation, developed on board a drilling ship due to the late discovery that HF use was prohibited. This author disaggregated wet silty clays samples in an electric blender. This was followed by prolonged heating in $20 \% \mathrm{HCl}$, followed by boiling with Calgon ${ }^{\circledR}$. This freed sufficient palynomorphs, which were isolated from the mineralrich residue using $\mathrm{ZnBr}_{2}$ gravity separation. Traverse (1978) stated that the traditional mineral acid preparation method used on the same samples onshore gave more concentrated and cleaner preparations. This non-HF method was also mentioned by Traverse (1988, p. 460). A similar method of dense-media separation for Quaternary organic-rich sediments and peats was described by Nakagawa et al. (1998).

Dodson (1983) described an experiment where he compared the results of a Quaternary pollen study in New South Wales, Australia using both acid digestion and ultrasonic dispersal of clays in $\mathrm{CHBr}_{3}$, followed by centrifugation as preparation methods. This author found that the ultrasonic-centrifugation method produced more concentrated pollen associations and less extraneous organic matter than acid digestion. However the ultrasonic treatment damages pollen grains with thin exines such as Chenopodiaceae and Poaceae (see also McIntyre \& Norris, 1964).

Herngreen (1983, p. 21) briefly mentioned the use of Darvan as a dispersant/deflocculant in palynological preparations. Darvan is a proprietary industrial dispersing agent and is known as lignosulphonic acid. It creates surface tension and causes separation of the finer, less dense, particles and settling of the coarser elements.

Heusser (1983) and Heusser \& Stock (1984) described a sieve-decant method for the concentration of pollen grains in organic-lean sediments. Here, clay-sized particles are deflocculated using a solution of $\mathrm{Na}_{4} \mathrm{P}_{2} \mathrm{O}_{7}$ and removed by sieving, leaving a palynomorph-rich residue which is then prepared in the traditional way using mineral acids. A method of palynological preparation suitable for fieldwork based on Heusser (1983) and Heusser \& Stock (1984) was outlined by Van Der Kaars \& Smit (1985). These authors adapted the sieve-decant method, omitting the mineral acid stages. They suspended $20 \mathrm{~cm}^{3}$ of crushed sample in $500 \mathrm{ml}$ of $10 \% \mathrm{Na}_{4} \mathrm{P}_{2} \mathrm{O}_{7}$ solution and left it to disaggregate for up to 24 hours. The sand and silt settles out relatively rapidly, leaving the bulk of the clay and palynomorphs in suspension. The suspension is then decanted and sieved at $7 \mu \mathrm{m}$. It was found that the addition of detergent at this stage allows the greater deflocculation of clay particles, thereby helping them to be sieved away and concentrating the palynomorphs. The palynomorph-rich residue is then washed using distilled water and alcohol, then stained and centrifuged. After the centrifuging stage, the palynomorphs are mounted on slides in the normal way (Van Der Kaars \& Smit, 1985, p. 494, 495). These authors reported that the palynological preparations using $\mathrm{Na}_{4} \mathrm{P}_{2} \mathrm{O}_{7}$ on Cretaceous and Palaeogene strata from Montana, USA are closely comparable to those prepared in the traditional way (see also Colbath, 1985).
Rueger (1986) developed a method using ethylenedinitrilotetraacetic acid (abbreviated to EDTA) for extracting palynomorphs from evaporites. This method was adapted from that of Bodine \& Fernalld (1973), and involves the removal of any water-soluble minerals, the residue is then boiled for four hours in a $0.25 \mathrm{M}$ solution of tetrasodium EDTA. Rueger (1986) stated that any remaining silicates could be removed using HF, however it is likely that density separation and/or clay disaggregation techniques will suffice to separate the palynomorphs from the silicate mineral fraction. Clay-Poole (1990) described a modified version of the technique described by Rueger (1986) for material from the arid south-west of the USA, which includes phases using both $\mathrm{HCl}$ and $\mathrm{HF}$.

Clarke (1994) described an experiment involving the preparation of modern material using the traditional HF/ acetolysis method and two non-acid techniques, i.e. sieving/ swirling and heavy liquid separation. It was determined that all three methods have benefits and disadvantages, however the HF/acetolysis method generally proved the most effective technique.

\section{THE EXTRACTION OF PALYNOMORPHS USING SODIUM HEXAMETAPHOSPHATE AS A DISAGGREGANT}

Because of the hazardous and expensive nature of $\mathrm{HCl}$, $\mathrm{HF}$ and $\mathrm{HNO}_{3}$, especially in the field or at a rigsite, an effective generic method of extracting palynomorphs that does not require the use of aggressive chemicals would be highly desirable. It is known that certain non-acid preparation techniques are currently in use, but precise details of these methods are not in the public domain (Williams et al., 2003). Consequently, a project to test the use of certain methods of disaggregation techniques was undertaken by the BGS palynological laboratory. Because alternative palynological preparation procedures inevitably will rely on chemical/ mechanical disaggregation of the mineral fabric, it was acknowledged that the best lithologies to test are relatively soft sedimentary rocks, which have not been intensively lithified, or unconsolidated sediments. Peterson et al. (1983) gave a brief review of the use of surfactants in disaggregating shales and other mudrocks. The technique described below is based around the deflocculating/sieving technique using $\mathrm{Na}_{2} \mathrm{CO}_{3}$ described by Eagar \& Sarjeant (1963) and the $\mathrm{HCl}$ and Calgon ${ }^{\circledR}$ method of Traverse $(1978,1988)$.

The disaggregating and deflocculating agent sodium hexametaphosphate $\left[\left(\mathrm{NaPO}_{3}\right)_{6}\right]$ was used in this pilot study. This substance is the active ingredient in the dispersant Calgon ${ }^{\circledR}$ (Hodginson, 1991). Sodium hexametaphosphate has been successfully used in the BGS laboratories in the preparation of calcareous microfaunas. This is only one of several methods of disaggregating sedimentary rock samples to separate foramininfera and ostracods from the matrix (see also Kummel \& Raup, 1965; Brasier, 1980). Several workers, however, have noted damage to calcareous microfossils using $\left(\mathrm{NaPO}_{3}\right)_{6}$. These include Oda et al. (1975), who reported that 


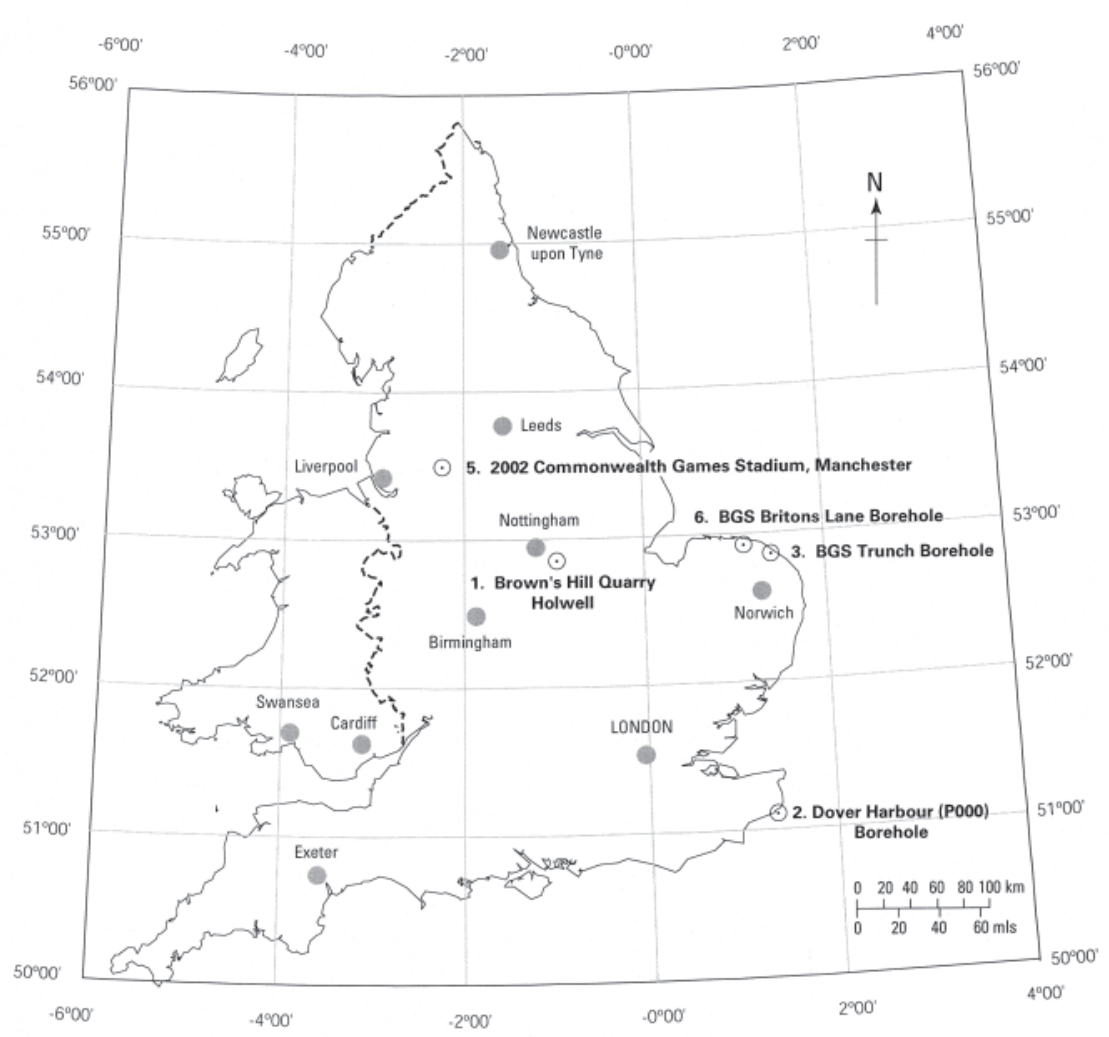

Figure 2. Location map of samples sets 1, 2, 3, 5 and 6 from England, UK.

typical of many inorganic salts, but it is relatively harmless if handled properly. No specific United Kingdom (UK) exposure limits have been assigned. In terms of an ecological/ environmental hazard, $\left(\mathrm{NaPO}_{3}\right)_{6}$ is not considered to be a dangerous substance, provided it is disposed of with due care and attention. Because it is a phosphate, if discharged in large amounts into a relatively small water body, it can cause eutrophication. In addition to disaggregating and deflocculating, $\left(\mathrm{NaPO}_{3}\right)_{6}$ is used commercially as a water softener, as a dispersant in the dyeing process, as a corrosion inhibitor for metals and in industrial cleaning.

In the methodology followed here, 42 rock samples of Jurassic to Quaternary age were selected for palynological preparation using both the traditional acid digestion technique and the new $\left(\mathrm{NaPO}_{3}\right)_{6}$ method. Selected samples were prepared using a quantitative technique (Harland, 1989), which allows palynomorphs extracted per unit mass of rock sample to be

a mixture of naptha and $\left(\mathrm{NaPO}_{3}\right)_{6}$ damaged Holocene planktonic foraminifera, and that this dissolution effect increased with concentration and exposure time. This corrosional effect on calcareous microfossils was also noted by Van Stuijvenberg (1979) and Hodgkinson (1991). Hay (1977) stated that $\left(\mathrm{NaPO}_{3}\right)_{6}$ at $\mathrm{pH}$ levels below 8 is corrosive to calcareous nannofossils. Despite this, in this study, $\left(\mathrm{NaPO}_{3}\right)_{6}$ was not noted to have any deleterious effects whatsoever on palynomorphs.

Phosphates in solution have a high ionic charge and, even at low concentrations, affect suspensions of colloidal particles (van Wazer, 1958; Bates et al., 1978). The phosphates generally are known as deflocculating, dispersing and peptising reagents. They reduce the coherent nature of the clay because phosphate ions are strongly adsorbed onto the clay particles, which break up because of the high ionic charges. The surface charges prevent any reflocculation of the clay.

Sodium hexametaphosphate (EC chemical number 223$343-1)$ is readily available from most chemical suppliers. It is a white, odourless, crystalline, inorganic salt that is extremely soluble in water and normally supplied in flake form. The substance is a chain phosphate and has many synonyms including metaphosphoric acid and Graham's Salt. It is not a toxic chemical and there is no evidence of carcinogenic properties or mutagenic/teratogenic effects. However the manufacturers advise that, if ingested in large amounts, it may cause nausea, vomiting, gastric pain and/or diarrhoea. It also may cause irritation to the eye. These properties are calculated. This method allows the effectiveness of both methods to be assessed objectively. The rock samples used are listed in Appendix 1. The preparation procedure using $\left(\mathrm{NaPO}_{3}\right)_{6}$ is outlined in detail in Figure 1 and Appendix 2. In summary, the rock samples are softened overnight using a strong detergent, treated with $\left(\mathrm{NaPO}_{3}\right)_{6}$, sieved, and mounted on microscope slides. Urgent ('hotshot') samples can be prepared omitting the overnight soak in water with detergent (step 2 of Figure 1 and step 1 of Appendix 2). The eventual palynomorph concentrate was generally found to be as rich and similarly preserved as those residues produced using the acid digestion process (see below). Another advantage with the $\left(\mathrm{NaPO}_{3}\right)_{6}$ process is that any silicofossils in the sample are also preserved. Commonly, this treatment does not disaggregate the whole of the rock sample. The method used here of ensuring that all the rock is broken down is that any remaining material is repeatedly treated with $\mathrm{H}_{2} \mathrm{O}_{2}$ to effect full disaggregation. While this strategy ensures that all the sample material is prepared, it is possible that the fraction subjected to $\mathrm{H}_{2} \mathrm{O}_{2}$ may be oxidised (Hopkins \& McCarthy, 2002). Hydrogen peroxide is an aggressive chemical and is known to corrode calcareous microfossils. Recent electronic correspondence on 'Paleonet' and other internet-based mailing lists has suggested that certain hair bleaching products, which contain peroxides at various concentrations, may also be useful in disaggregating sedimentary rocks. No recorded testing of this method, however, is available. 


\section{CASE STUDIES}

In this section, seven case studies using the $\left(\mathrm{NaPO}_{3}\right)_{6}$ palynological preparation process are described. Five of these studies have used both the acid and $\left(\mathrm{NaPO}_{3}\right)_{6}$ methods in order to compare them and four are quantitative in order to effect objective comparisons of the two procedures. The geographical locations of all seven intervals studied and selected photomicrographs are given as Figures 2 to 7 . Figure 3 is a montage of individual palynomorphs prepared using the $\left(\mathrm{NaPO}_{3}\right)_{6}$ procedure. Relatively low magnification photomicrographs directly compare both preparation procedures in Figure 4 and illustrate examples of the $\left(\mathrm{NaPO}_{3}\right)_{6}$ preparation technique in Figure 6. All taxa at and below species level mentioned in this contribution are listed in Appendix 3.

All the specimens illustrated in Figures 3, 4 and 6 are curated in the British Geological Survey palynological collections. The specimens in Figure 3 are curated in the figured specimen ('MPK') collection and the low magnification views in Figures 4 and 6 are of slides that are in the micropalaeontological/palynological ('MPA') collection.

\section{The Lower Jurassic of Holwell Quarry, Leicestershire, UK (both preparation methods, non-quantitative)}

Fourteen samples of the Lower Jurassic (Upper Pliensbachian to Lower Toarcian) Lias Group succession at Brown's Hill Quarry, Holwell, Leicestershire, central England (Figure 2; Clements, 1989), were prepared using both the traditional mineral acid method and $\left(\mathrm{NaPO}_{3}\right)_{6}$. Holwell Quarry is a disused ironstone quarry and an important reference section for the Upper Pliensbachian and Lower Toarcian in the East Midlands; the palynology of this succession was described by Riding (2002a). This succession was chosen for study because it includes both limestones and organicrich claystones, hence some lithological comparisons can be made. The samples are listed in Appendix 1 and the results illustrated in Table 1. These samples were not prepared quantitatively in order to test the $\left(\mathrm{NaPO}_{3}\right)_{6}$ method under normal laboratory conditions. Routinely, most palynology samples are prepared using a non-quantitative preparatory technique.

The samples are variably palynologically productive. Samples 14 to 9 from the Dyrham and Marlstone Rock formations are sparse in palynomorphs and other plant phytoclasts. Preservation is generally poor and this is thought to be due to these sandstones and limestones being organic-lean and also possibly having being highly weathered. The palynofloras are dominated by pollen and spores but also include some marine microplankton, principally the prasinophyte Halosphaeropsis liassica and dinoflagellate cysts. Because the $\left(\mathrm{NaPO}_{3}\right)_{6}$ preparation method uses this reagent as a disaggregant, it was somewhat surprising that it proved successful in preparing samples 13 to 9 from the Marlstone Rock Formation at this locality. This unit is a hard, splintery, chamosite oolite. However, the Marlstone Rock Formation is clearly primarily organic-lean at Holwell, so this may not be an entirely suitable test for limestones.

By contrast, the samples from the Whitby Mudstone Formation, numbers 8 to 1 , are significantly richer and wellpreserved (Table 1). The principal reasons for this major

Table 1. Numbers of palynomorphs per microscope slide from samples 14 to 1 from the Lower Jurassic of Holwell Quarry, prepared nonquantitatively using both methods. The largest within the respective pairs of figures are emboldened. The two right hand columns are a comparison between the two methods: these comprise the number of grains per slide from the acid method, minus this figure for the $\left(\mathrm{NaPO}_{3}\right)_{6}$ procedure (Difference in number), and the percentage of this difference with respect to the overall count (Difference in \%) for both methods respectively. Where the $\left(\mathrm{NaPO}_{3}\right)_{6}$ method produced a higher number of palynomorphs per slide, these figures are emboldened. Abbreviations: $\mathrm{D}$, dinoflagellate cysts; $\mathrm{M}$, miospores; $\mathrm{P}$, palynomorphs; $\mathrm{V}$, various microplankton.

\begin{tabular}{|c|c|c|c|c|c|c|c|c|c|c|}
\hline \multirow{2}{*}{$\begin{array}{c}\text { Sample } \\
\quad \#\end{array}$} & \multicolumn{4}{|c|}{ Mineral Acid } & \multicolumn{4}{|c|}{ Sodium hexametaphosphate } & \multirow{2}{*}{$\begin{array}{l}\text { Difference } \\
\text { in number }\end{array}$} & \multirow{2}{*}{$\begin{array}{c}\text { Difference } \\
\%\end{array}$} \\
\hline & $\mathbf{P}$ & M & D & V & $\mathbf{P}$ & M & D & V & & \\
\hline 1 & 6297 & 1007 & 3 & 5289 & 10721 & 1613 & 27 & 9081 & -4424 & $26,00 \%$ \\
\hline 2 & 2797 & 370 & $\ldots$ & 2427 & 2164 & 415 & $\ldots$ & 1749 & +633 & $12,76 \%$ \\
\hline 3 & 6004 & 940 & $\ldots$ & 5064 & 5444 & 1070 & 8 & 4366 & +560 & $4,89 \%$ \\
\hline 4 & 6228 & 2710 & 4 & 3514 & 6529 & 3941 & 43 & 2545 & -301 & $2,36 \%$ \\
\hline 5 & 3185 & 938 & $\ldots$ & 2247 & 2011 & 918 & 7 & 1086 & +1174 & $22,59 \%$ \\
\hline 6 & 9047 & 2769 & 4 & 6274 & 8995 & 4088 & 32 & 4875 & +52 & $0,29 \%$ \\
\hline 7 & 4803 & 1105 & 3 & 3695 & 8046 & 4106 & 11 & 3929 & -3243 & $25,24 \%$ \\
\hline 8 & 5240 & 693 & $\ldots$ & 4547 & 4376 & 613 & 3 & 3760 & +864 & $8,99 \%$ \\
\hline 9 & 32 & 32 & 1 & $\ldots$ & 53 & 40 & 2 & 11 & -21 & $24,71 \%$ \\
\hline 10 & 505 & 321 & 10 & 174 & 126 & 93 & .. & 33 & +379 & $60,06 \%$ \\
\hline 11 & 24 & 21 & $\ldots$ & 3 & 133 & 105 & 2 & 26 & -109 & $69,43 \%$ \\
\hline 12 & 2 & 2 & $\ldots$ & $\ldots$ & 67 & 52 & $\ldots$ & 15 & -65 & $94,20 \%$ \\
\hline 13 & 5 & 4 & $\ldots$ & 1 & 33 & 18 & $\ldots$ & 15 & -28 & $73,68 \%$ \\
\hline 14 & 5 & 5 & $\ldots$ & $\ldots$ & 11 & 6 & $\ldots$ & 5 & -6 & $37,50 \%$ \\
\hline
\end{tabular}


disparity in productivity are the relative organic richness of the Whitby Mudstone Formation and the overwhelming abundance of the prasinophyte species Halosphaeropsis liassica in this unit. This taxon dominates the miscellaneous microplankton counts in samples 8 to 1 (Table 1) and the dominance of Halosphaeropsis liassica is typical of the early Toarcian of north-west Europe (Bucefalo Palliani \& Riding, 2000). Other miscellaneous microplankton and dinoflagellate cysts are also more diverse and prominent than those from the underlying succession. Samples 8 to 1 are also rich in amorphous organic material, which is a reflection of the oceanic anoxic event (Bucefalo Palliani \& Riding, 1999; Bucefalo Palliani et al., 2002). Miospores are present throughout and are the most diverse palynomorph group. They include undifferentiated bisaccate pollen, Cerebropollenites macroverrucosus, Chasmatosporites spp., Cibotiumspora juriensis, Classopollis classoides, Classopollis meyeriana, Concavissimisporites verrucosus, Contignisporites spp., Coronatispora valdensis, Cyathidites spp., Dictyophyllidites spp., Ischyosporites variegatus, Osmundacidites wellmanii, Perinopollenites elatoides, Retitriletes austroclavatidites and Todisporites spp. These associations are typical of the late Pliensbachian-early Toarcian interval (Srivastava, 1984). Dinoflagellate cysts are largely confined to the Whitby Mudstone Formation and include Mancodinium semitabulatum, Nannoceratopsis deflandrei subsp. deflandrei, Nannoceratopsis deflandrei subsp. senex, Nannoceratopsis gracilis, Pareodinia sp. and Scriniocassis weberi. Other prasinophytes comprise species of Cymatiosphaera and Tasmanites. These associations are also characteristic of the late Pliensbachian-early Toarcian interval (Bucefalo Palliani \& Riding, 2000). For example, the cooccurrences of the dinoflagellate cysts Mancodinium semitabulatum, Nannoceratopsis deflandrei subsp. deflandrei, Nannoceratopsis deflandrei subsp. senex and Nannoceratopsis gracilis are indicative of the earliest Toarcian (Riding et al., 1991; Riding \& Thomas, 1992). The range bases of the dinoflagellate cyst Nannoceratopsis gracilis and the pteridophyte spore Ischyosporites variegatus are also reliable early Toarcian markers (Riding et al., 1999). It is unsurprising that the Whitby Mudstone Formation samples prepared using $\left(\mathrm{NaPO}_{3}\right)_{6}$ yielded similar associations as those prepared using the traditional acid procedure. This unit comprises relatively soft shales and mudstones and $\left(\mathrm{NaPO}_{3}\right)_{6}$ is known to be a highly efficient disaggregant of clays.

The two preparation methods for these samples generally produced comparable palynomorph associations in terms of species spectra, diversities and absolute numbers (Table 1; Figures $3 \mathrm{~A}-3 \mathrm{H})$. Furthermore, the kerogen associations are also similar and preservation levels are comparable (Figures 4A, 4B). When comparing the palynological yields for each method, it should be borne in mind that the data in Table 1 are not quantitative. The numbers are simply counts per microscope slide and several factors during the preparation process may have biased these yields. These include the mass of rock processed, the concentration of palynomorphs in the final liquid residue and the amount of residue placed on the coverslip. However, it is anticipated that any significant trends will be clearly manifested. It is difficult to generalise about the palynological yields from the entire succession. For the Dyrham and Marlstone Rock formations (samples 14 to 9), the subsample set prepared using $\left(\mathrm{NaPO}_{3}\right)_{6}$ proved to be generally the most palynologically productive. Here, all the samples except sample 10 produced more palynomorphs than the acid method, and in samples 12, 11 and 9, this difference is significant (Table 1). This trend is not evident in sample 10, which produced significantly more palynomorphs using the acid method than the $\left(\mathrm{NaPO}_{3}\right)_{6}$ procedure. Samples 14 and 13 proved to be primarily sparse in palynomorphs. The eight samples from the Whitby Mudstone Formation all produced abundant palynofloras for both preparation methods. Five of these were more productive using mineral acids (Table 1). The differences vary in magnitude, but are generally relatively low. The productivity of Sample 6 is virtually identical using both methods. However, sample 5 proved much more productive using mineral acids. For the three samples which were palynologically richer using $\left(\mathrm{NaPO}_{3}\right)_{6}$, numbers 7 and 1 were markedly different and sample 4 was virtually identical.

Comparisons of the data in Table 1 indicate that palynomorph taxa only observed in the acid preparation slides are extremely rare. There may, however, be certain palynomorph groups best suited to one or other of the preparation methods. For example, four out of the five samples that yielded foraminiferal test linings were those prepared using acid maceration. It is possible that these forms were lost during decantation. The pollen grain Perinopollenites elatoides and the spores Contignisporites spp. and Todisporites minor are present more often in samples prepared using mineral acids. Additionally, dinoflagellate cysts are more diverse in samples 11 and 5 prepared using acid, as compared to those samples which were treated with $\left(\mathrm{NaPO}_{3}\right)_{6}$. These differences are, however, relatively minor and are deemed to be well within the range of the known natural variability of Toarcian dinoflagellate cyst associations (Bucefalo Palliani \& Riding, 2003). The results from the Holwell Quarry samples indicate that the $\left(\mathrm{NaPO}_{3}\right)_{6}$ preparation method appears to work well with both organic-lean, hard limestones and soft, organicrich shales.

\section{The Lower Cretaceous of the Dover Harbour (P000) Borehole, Kent, UK (both preparation methods, quantitative)}

Ten samples of the Gault Formation (Middle and Upper Albian), from the Dover Harbour (P000) Borehole, Kent, south-east England, were studied (Figure 2). The Gault Formation is a shallow water claystone deposit (Owen et al., 1996). All the samples are of mid grey, calcareous mudstones. This borehole was drilled as part of the site investigations for the Channel Tunnel and was mentioned by ShephardThorn (1988) and Hart (1993). The samples were prepared quantitatively using both the traditional mineral acid method and $\left(\mathrm{NaPO}_{3}\right)_{6}$. The quantitative method was used for both preparation methods in order to test whether the two procedures produce similar numbers of palynomorphs per unit mass of rock in a well-lithified mudstone succession. 

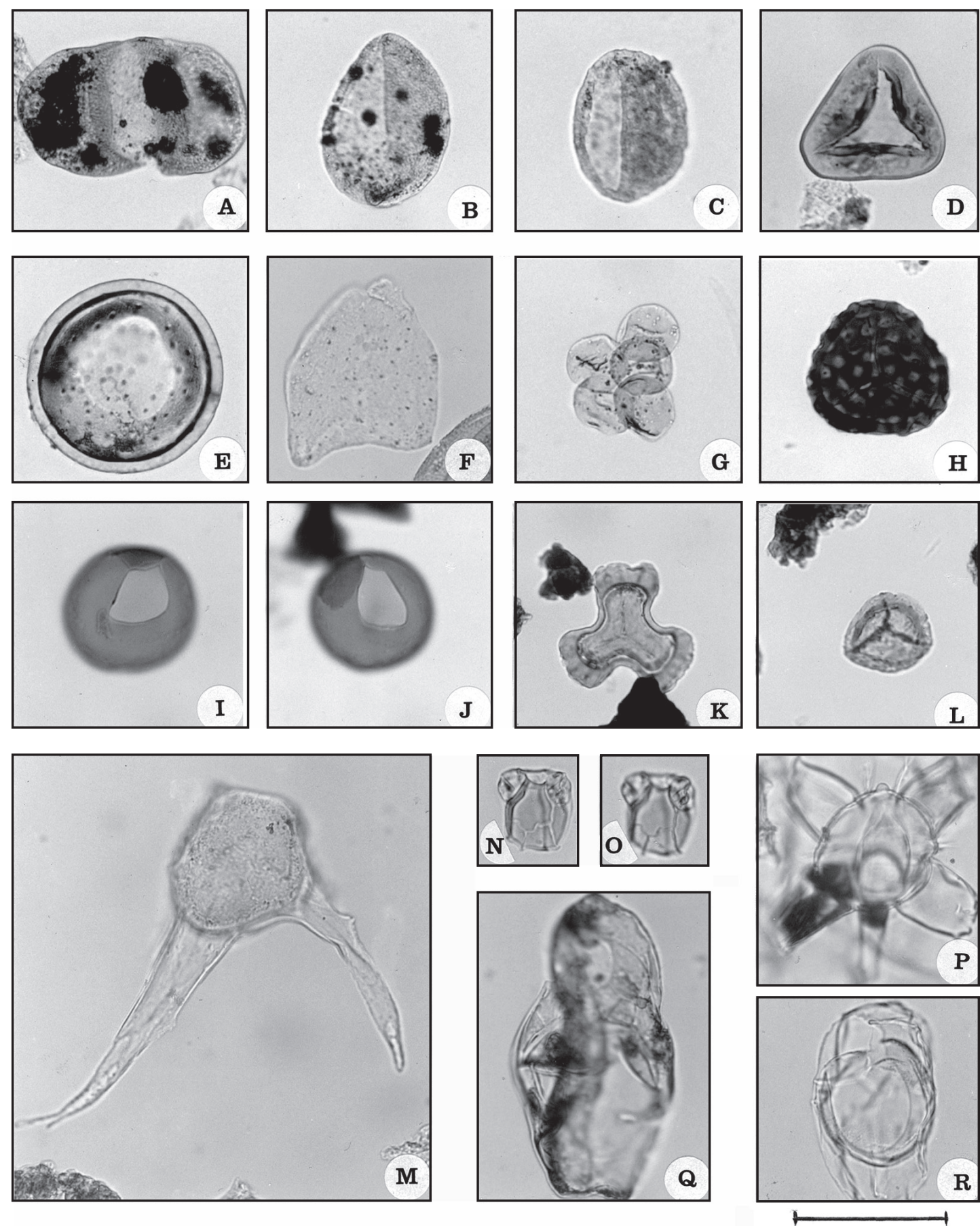

Figure 3. Examples of palynomorphs that were prepared using the sodium hexametaphosphate procedure from the case studies described herein. Scale bar $=50 \mu \mathrm{m}$. A. Alisporites sp. Brown's Hill Quarry, Holwell, Whitby Mudstone Formation, Lower Toarcian. Sample 4, specimen MPK 12769. B, C. Chasmatosporites spp. Brown's Hill Quarry, Holwell, Marlstone Rock Formation, Lower Toarcian. B - sample 11, specimen MPK 12770. C - sample 10, specimen MPK 12771. D. Cyathidites australis, location/stratigraphical details as A. Sample 6, specimen MPK 12772. E. Tasmanites newtoni, location/stratigraphical details as A. Sample 3, specimen MPK 12773. F. Nannoceratopsis deflandrei deflandrei, location/stratigraphical details as A. Sample 4, specimen MPK 12774. G. Halosphaeropsis liassica, location/ stratigraphical details as A. Sample 4, specimen MPK 12775. H. Ischyosporites variegatus, location/stratigraphical details as A. Sample 8 , specimen MPK 12776. I, J. Brigantedinium simplex, BGS offshore borehole 56-10/249 CS, Quaternary brown/black clay. I - sample 40, specimen MPK 12777. J - sample 40, specimen MPK 12778. K. Tripartites vetustus (reworked), location/stratigraphical details as I, J. Sample 40, specimen MPK 12779. L. Lycospora pusilla (reworked) Commonwealth Games Stadium site, Manchester, Upper Pleistocene Till. Sample 36, specimen MPK 12780. M. Odontochitina operculata (reworked), BGS Britons Lane Borehole, Quaternary diamicton. Sample 39, specimen MPK 12781. N, O. Gillinia hymenophora (reworked), N- median focus; O- low focus. location/stratigraphical details as M. Sample 38, specimen MPK 12782. P. Neoeurysphaeridium glabrum (reworked), location/stratigraphical details as M. Sample 39, specimen MPK 12783. Q. Isabelidinium sp. cf. I. pellucidum, Bodman Point, Seymour Island, Antarctica, López de Bertodano Formation. Sample 35, specimen MPK 12784. R. Hystrichosphaeropsis quasicribrata (reworked), location/stratigraphical details as M. Sample 38, specimen MPK 12785. 
The samples are listed in Appendix 1 and the results tabulated in Table 2.

The samples proved variably palynologically productive and are normally dominated by dark wood phytoclasts and dinoflagellate cysts; other plant tissues, amorphous organic material and miospores are generally less common. Prominent dinoflagellate cysts include Cribroperidinium? edwardsii, Cribroperidinium sepimentum, Cyclonephelium compactum, Odontochitina operculata, Oligosphaeridium spp., Spiniferites ramosus and Spiniferites spp. Lower proportions of Chlamydophorella nyei, Coronifera oceanica, Florentinia mantellii, Fromea amphora, Hystrichodinium spp., Ovoidinium scabrosum, Protoellipsodinium spinocristatum, Scriniodinium campanula, Stephodinium coronatum, Subtilisphaera perlucida and Wrevittia cassidata were also observed. Prominent miospores include bisaccate pollen and pteridophtic spores. The palynomorph assemblages were comparable to those described from the Albian of north-west Europe by Cookson \& Hughes (1964), Kemp (1970), Davey \& Verdier (1971; 1973) and Nøhr-Hansen (1993). The palynomorph assemblages are broadly similar in assemblage compositions and relative proportions throughout the succession studied, indicating it lies within a single genetic sequence.

The different preparation styles of these ten samples normally produced comparable organic residues and palynofloras (Figures 4C, 4D). In five samples, the differences between the numbers of palynomorphs per gram produced by the two procedures accounts for less than $10 \%$ of the total palynomorph sum (Table 2). In sample 17, for example, this difference is only $2.77 \%$ and the two preparations are virtually indistinguishable. The two methods of preparing sample 16 also gave extremely similar organic residues. Samples 24, 23, 22, 20, 19 and 18 prepared using $\left(\mathrm{NaPO}_{3}\right)_{6}$ produced cleaner palynofloras which were easier to study than when prepared using acids. Specifically, these $\left(\mathrm{NaPO}_{3}\right)_{6}$ preparations produced less amorphous organic material and resistant mineral grains than when prepared with acid. Furthermore, in six of the samples, the $\left(\mathrm{NaPO}_{3}\right)_{6}$ preparations produced more palynomorphs per gram than when the samples were prepared using acids (Table 2). Samples 23, 19 and 18 prepared using $\left(\mathrm{NaPO}_{3}\right)_{6}$ were significantly richer than when prepared using acid. In the case of sample 18, the mineral acid preparation is dominated by dark amorphous organic material, which is not present in the $\left(\mathrm{NaPO}_{3}\right)_{6}$ preparation. However, in sample 21, the mineral acid procedure produced a far richer association than the $\left(\mathrm{NaPO}_{3}\right)_{6}$ preparation. This disparity is largely due to a much reduced level of dinoflagellate cysts in the $\left(\mathrm{NaPO}_{3}\right)_{6}$ slides (Table 2). Sample 15 also produced considerably more palynomorphs per gram using mineral acid than when prepared using $\left(\mathrm{NaPO}_{3}\right)_{6}($ Table 2 ). The reasons for these differences are not clear; there were no discernible lithological difference between all ten samples.

Because miospores, dinoflagellate cysts and various microplankton are normally present in similar relative proportions, the two preparation methods appear to lack bias for or against any single palynomorph group. The ten samples from the Dover Harbour Borehole strongly suggest that the $\left(\mathrm{NaPO}_{3}\right)_{6}$ preparation method is suitable for use on successions of moderately lithified mudrocks. In most cases, the palynomorph associations are richer and cleaner than samples prepared using the traditional mineral acid method. This may be due to the loss of some of the buoyant palynomorphs during decantation in the acid procedure.

\section{The Upper Cretaceous of the BGS Trunch Borehole,} Norfolk, UK (both preparation methods, quantitative)

Five samples of the White Chalk Subgroup, from the Trunch stratigraphical borehole in north Norfolk, south-east

Table 2. Numbers of palynomorphs per gram from samples 24 to 15 from the Dover Harbour (P000) Borehole, Kent, prepared quantitatively using both methods. The largest within the respective pairs of figures are emboldened. The two right hand columns are a comparison between the two methods: these comprise the number of grains per slide from the acid method, minus this figure for the $\left(\mathrm{NaPO}_{3}\right)_{6}$ procedure (Difference in number), and the percentage of this difference with respect to the overall count (Difference in \%) for both methods respectively. Where the $\left(\mathrm{NaPO}_{3}\right)_{6}$ preparation method has produced a higher number of palynomorphs per gram, these figures are emboldened. Abbreviations: D, dinoflagellate cysts; M, miospores; P, palynomorphs; V, various microplankton.

\begin{tabular}{|c|c|c|c|c|c|c|c|c|c|c|}
\hline \multirow{2}{*}{$\begin{array}{c}\text { Sample } \\
\#\end{array}$} & \multicolumn{4}{|c|}{ Mineral Acid method } & \multicolumn{4}{|c|}{ Sodium hexametaphosphate method } & \multirow{2}{*}{$\left|\begin{array}{l}\text { Difference } \\
\text { in number }\end{array}\right|$} & \multirow{2}{*}{$\begin{array}{l}\text { Difference } \\
\text { in } \%\end{array}$} \\
\hline & $\mathbf{P}$ & $\mathbf{M}$ & D & $\mathbf{v}$ & $\mathbf{P}$ & M & D & $\mathbf{v}$ & & \\
\hline 15 & 4887 & 353 & 4405 & 129 & 3867 & 397 & 3331 & 139 & +1020 & $11,65 \%$ \\
\hline 16 & 1249 & 173 & 1043 & 33 & 1451 & 225 & 1150 & 76 & -202 & $7,48 \%$ \\
\hline 17 & 2429 & 281 & 2031 & 117 & 2298 & 346 & 1876 & 76 & +131 & $2,77 \%$ \\
\hline 18 & 1202 & 169 & 1001 & 32 & 2081 & 210 & 1827 & 44 & -879 & $26,77 \%$ \\
\hline 19 & 1637 & 174 & 1337 & 126 & 2236 & 250 & 1881 & 105 & -599 & $15,46 \%$ \\
\hline 20 & 4036 & 348 & 3601 & 137 & 4766 & 483 & 4162 & 121 & -730 & $8,29 \%$ \\
\hline 21 & 4627 & 436 & 4067 & 124 & 1199 & 319 & 805 & 75 & +3428 & $58,83 \%$ \\
\hline 22 & 4375 & 523 & 3753 & 99 & 4847 & 779 & 3910 & 158 & -472 & $5,12 \%$ \\
\hline 23 & 4499 & 435 & 3847 & 217 & 8377 & 889 & 7185 & 303 & -3878 & $30,12 \%$ \\
\hline 24 & 5163 & 755 & 4148 & 260 & 4312 & 656 & 3434 & 222 & +851 & $8,98 \%$ \\
\hline
\end{tabular}



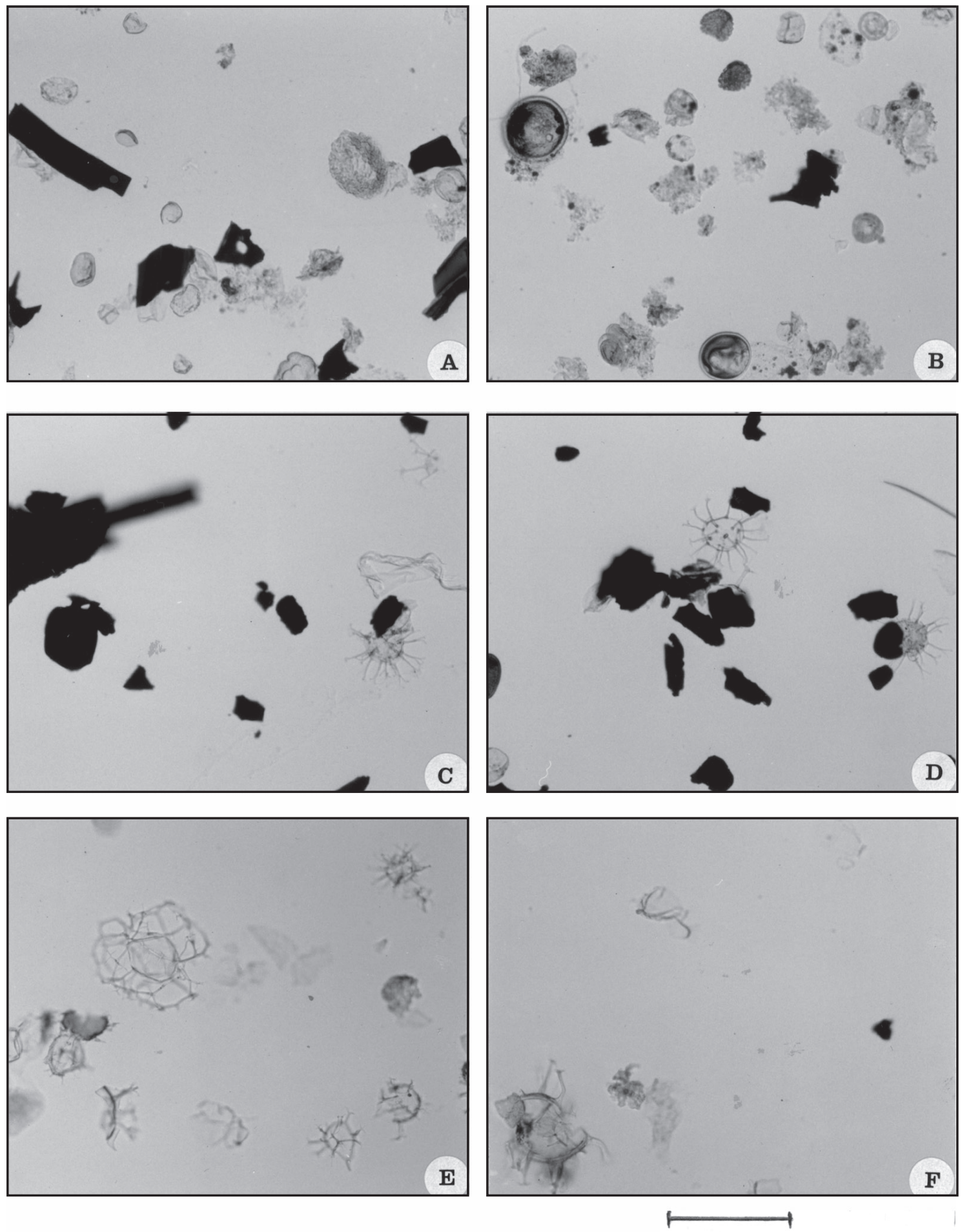

Figure 4. Direct comparisons of the mineral acid preparation technique (A, C, E) with the sodium hexametaphosphate ('hexa') procedure $(B, D, F)$. Scale bar $=100 \mu \mathrm{m}$. A, B. Brown's Hill Quarry, Holwell, Whitby Mudstone Formation, Lower Toarcian. A. mineral acid preparation. Sample 4, 'acid' slide MPA 50794/2, Q51. B. sodium hexametaphosphate procedure. Sample details as A, 'hexa' slide MPA 50794/2, O52/ 2. Note the overall similarities of these non-quantitative preparations. There is a specimen of Cerebropollenites macroverrucosus in photomicrograph A and two specimens of Tasmanites in photomicrograph B. C, D. Dover Harbour Borehole, Lower Gault Formation, Middle Albian. C. mineral acid preparation. Sample 22, 'acid' slide MPA 50936/2, R50/4. D. sodium hexametaphosphate procedure. Sample details as C, 'hexa' slide MPA 50936/2, N54/3. The preparations are both quantitative; note the overall similarities of the two residues and the preponderance of chorate (spine-bearing) dinoflagellate cysts. E, F. BGS Trunch Borehole, Paramoudra Chalk, Upper Campanian. E. hydrochloric acid preparation. Sample 29, 'acid' slide MPA 50898/2, K54/2. F. sodium hexametaphosphate procedure. Sample details as E, 'hexa' slide MPA 50898/2, O56/1. The preparations are both quantitative; note the significantly better palynological productivity in the acid preparation; the sodium hexametaphosphate preparation is relatively palynologically sparse. Note the specimen of Cannosphaeropsis utinensis in $\mathrm{E}$. 
England (Figure 2), were examined. The samples are all of greyish white to white chalk with minor wispy marl flasers and which is occasionally burrowed. The Chalk Group is a marine micritic limestone, largely comprising calcareous nannofossils and deposited in a warm palaeoclimate in relatively deep waters (Hancock, 1975). Modern accounts of the stratigraphy of the Chalk Group of southern England were given by Bristow et al. (1997) and Rawson et al. (2001), although the lithostratigraphy of this unit in north Norfolk remains to be revised. These samples of Campanian-Maastrichtian chalk were all prepared quantitatively using both a modified mineral acid technique and the $\left(\mathrm{NaPO}_{3}\right)_{6}$ procedure. The acid procedure used on these samples omitted the use of HF. Both authors have found that the treatment of $\mathrm{HCl}$ to large, non-marly Chalk Group samples effectively releases the palynomorphs from the rock matrix, thereby rendering the use of HF entirely superfluous. The quantitative method was used here to test if these two techniques yield comparable quantities of palynomorphs per unit mass of rock in a relatively organic-lean limestone. The samples are listed in Appendix 1 and the results tabulated in Table 3.

The samples proved moderately palynologically productive and are dominated by well-preserved dinoflagellate cysts. Other palynomorphs are rare and wood fragments are consistently present. Other plant tissues, amorphous organic material and resistant mineral grains are also present in variable proportions. Low numbers of reworked Carboniferous spores (Densosporites spp. and Lycospora pusilla) were noted in most of the samples. The Chalk Group is a pure coccolith-rich limestone and consequently profoundly organic-lean; this is reflected in the relatively low numbers of palynomorphs per gram of rock (Table 3). Prominent dinoflagellate cysts include Alisogymnium euclaense, Cannosphaeropsis utinensis, Circulodinium distinctum, Cladopyxidium paucireticulatum, Cladopyxidium spp., Dinogymnium spp., Exochosphaeridium bifidum, Exochosphaeridium phragmites, Exochosphaeridium spp., Gillinia hymenophora, Hystrichosphaeridium tubiferum, Hystrichosphaeropsis quasicribrata, Isabelidinium spp., Membranilarnacia angustivela (=
'Samlandia solida' of Wilson, 1974), Microdinium bensonii, Microdinium granocarinatum, Microdinium spp., Neoeurysphaeridium glabrum, Odontochitina operculata, Palaeoperidinium pyrophorum, Palaeotetradinium maastrichtiense, Rottnestia wetzelii, Spiniferites ramosus, Spiniferites spp., Spongodinium delitiense, Trithyrodinium spp., Xenascus ceratioides, Xenikoon sp. and Xiphophoridium alatum. Several of these forms have restricted stratigraphical ranges and are entirely consistent with the late Campanian and early Maastrichtian age of the samples. The floras are similar to coeval associations described from northern Europe (Wilson, 1974; Foucher, 1979; Robaszynski et al., 1985; Herngreen et al., 1986; Schiøler \& Wilson, 1993; Slimani, 1994, 1996).

Counts of palynomorphs per gram for the two methods (Table 3) indicate that the $\mathrm{HCl}$ preparation technique largely yielded richer palynofloras than those prepared using $\left(\mathrm{NaPO}_{3}\right)_{6}$ (see also Figures 4E, 4F). Only the uppermost sample, number 25 , produced less palynomorphs using the acid method. Samples 29 to 26 produced relatively abundant palynofloras using $\mathrm{HCl}$; the palynomorph yield using $\left(\mathrm{NaPO}_{3}\right)_{6}$ was significantly lower. This disparity was most marked in samples 27 and 26 (Table 3). Furthermore, the palynomorph preservation of the acid method samples was consistently significantly better than those prepared using $\left(\mathrm{NaPO}_{3}\right)_{6}$ (Figures $\left.4 \mathrm{E}, 4 \mathrm{~F}\right)$. The acid preparations of samples 29,27 and 26 proved more conducive to microscopical study as they have considerably less extraneous material than is in the $\left(\mathrm{NaPO}_{3}\right)_{6}$ preparations. The relative proportions of the three palynomorph groups are somewhat variable. Because of the overwhelming dominance of dinoflagellate cysts, these palynomorphs consistently reflect the differences in overall numbers between the two preparation methods. However, the concentrations of miscellaneous microplankton (acritarchs, foraminiferal test linings, prasinophytes etc.) are largely similar for each preparation method (Table 3). Only in sample 29 are the miscellaneous microplankton proportional to the overall palynomorph concentrations. In samples 29, 26 and 25 , the miospore concentrations are also proportional to the entire palynoflora. Samples 28 and 27, however, are

Table 3. Numbers of palynomorphs per gram from samples 29 to 25 from the Trunch Borehole, Norfolk, prepared quantitatively using both methods. The largest within the respective pairs of figures are emboldened. The two right hand columns are a comparison between the two methods: these comprise the number of grains per gram from the acid method, minus this figure for the $\left(\mathrm{NaPO}_{3}\right)_{6}$ procedure $(\mathrm{Difference}$ in number), and the percentage of this difference with respect to the overall count (Difference in \%) for both methods respectively. Where the $\left(\mathrm{NaPO}_{3}\right)_{6}$ preparation method has produced a higher number of palynomorphs per gram, these figures are emboldened. Abbreviations: $\mathrm{D}$, dinoflagellate cysts; $\mathrm{M}$, miospores; P, palynomorphs; V, various microplankton.

\begin{tabular}{c|c|c|c|c|c|c|c|c|c|c} 
Sample & \multicolumn{4}{|c|}{ Mineral Acid (HCI) } & \multicolumn{4}{|c|}{ Sodium hexametaphosphate } & Difference & Difference \\
\cline { 2 - 11 }$\#$ & $\mathbf{P}$ & $\mathbf{M}$ & $\mathbf{D}$ & $\mathbf{V}$ & $\mathbf{P}$ & $\mathbf{M}$ & $\mathbf{D}$ & $\mathbf{V}$ & in number & in \% \\
\hline $\mathbf{2 5}$ & $\mathbf{2 5 9}$ & 11 & 243 & $\mathbf{5}$ & $\mathbf{3 9 2}$ & $\mathbf{1 4}$ & $\mathbf{3 7 1}$ & $\mathbf{7}$ & $\mathbf{- 1 3 3}$ & $\mathbf{2 0 , 4 3 \%}$ \\
$\mathbf{2 6}$ & $\mathbf{4 3 1}$ & $\mathbf{1 7}$ & $\mathbf{4 0 8}$ & $\mathbf{6}$ & 113 & 6 & 103 & 4 & +318 & $58,46 \%$ \\
$\mathbf{2 7}$ & $\mathbf{7 3 2}$ & $\mathbf{1 5}$ & $\mathbf{7 0 7}$ & $\mathbf{1 0}$ & 228 & 14 & 207 & 7 & +504 & $52,50 \%$ \\
$\mathbf{2 8}$ & $\mathbf{4 2 5}$ & $\mathbf{7}$ & $\mathbf{4 0 7}$ & $\mathbf{1 1}$ & 258 & $\mathbf{1 3}$ & 235 & 10 & +167 & $24,45 \%$ \\
$\mathbf{2 9}$ & $\mathbf{4 8 0}$ & $\mathbf{3 8}$ & $\mathbf{4 3 3}$ & $\mathbf{9}$ & 190 & $\mathbf{8}$ & 177 & 5 & +290 & $43,28 \%$ \\
\hline
\end{tabular}



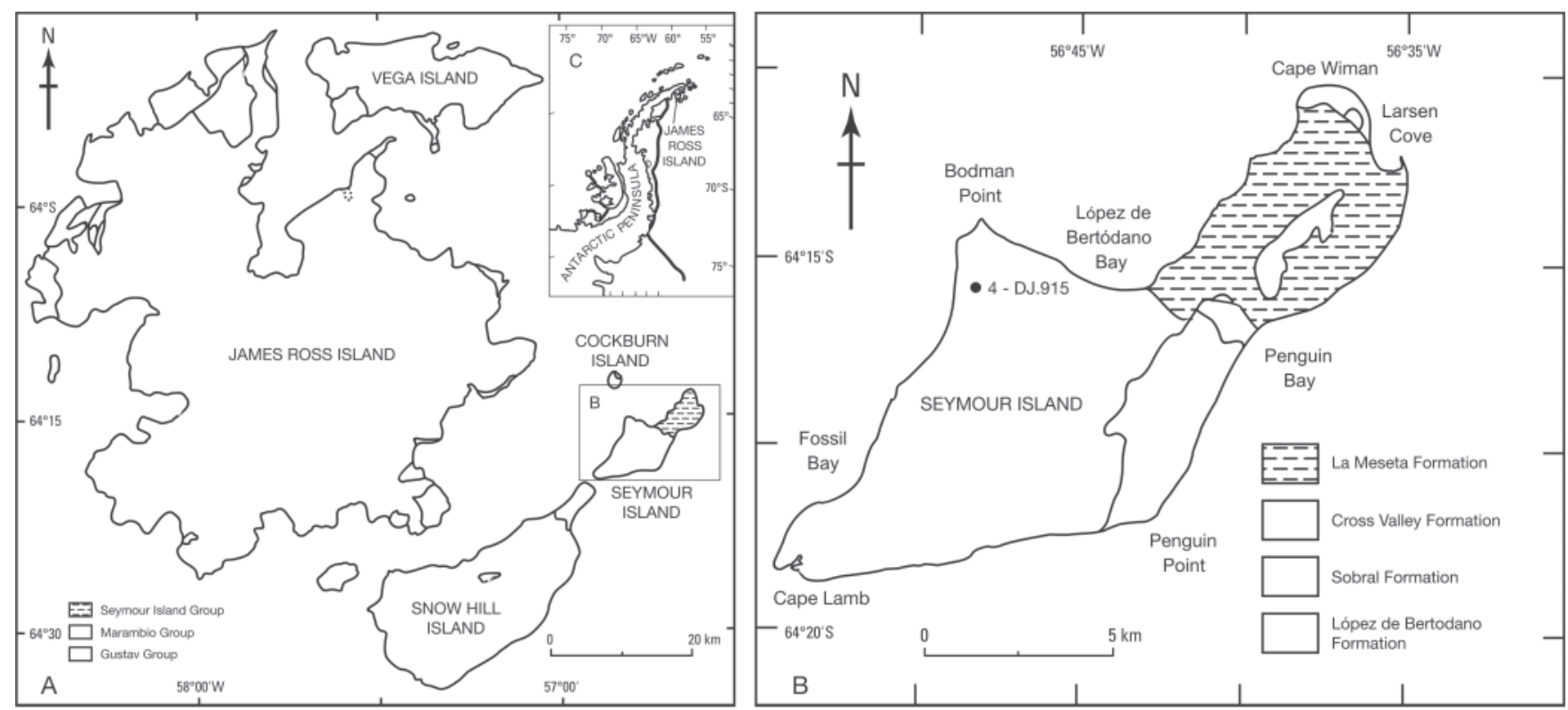

Figure 5. Location map of sample set 4, from south of Bodman Point, Seymour Island, Antarctica (adapted from Pirrie et al., 1998). A. The James Ross Island archipelago, northern Antarctic Peninsula. B. Detail of Seymour Island, illustrating the location of sample set 4. C. The Antarctic Peninsula region.

significantly anomalous. In sample 28 , the mineral acid method produced considerably more palynomorphs than the $\left(\mathrm{NaPO}_{3}\right)_{6}$ procedure; paradoxically, the latter preparation method produced almost double the concentrations of miospores in comparison to the acid technique. Furthermore, the levels of miospores in sample 27 are virtually identical for both preparation methods (Table 3). These anomalies are not considered to be statistically significant and thus do not indicate that the two preparation methods may introduce marked preservational biases within the different palynomorph groups. This is because the levels of miospores and miscellaneous microplankton in the Chalk Group are extremely low. These samples indicate that the $\mathrm{HCl}$ digestion technique is significantly more effective than the $\left(\mathrm{NaPO}_{3}\right)_{6}$ method for the palynological preparation of samples from the Chalk Group (Figures 4E, 4F). The reason for this phenomenon is that the $\left(\mathrm{NaPO}_{3}\right)_{6}$ is not an effective disaggregant of pure limestones. Phosphates specifically disaggregate and deflocculate clays and other colloids. The results here suggest that calcite is more resistant to $\left(\mathrm{NaPO}_{3}\right)_{6}$. This is confirmed by workers on calcareous microfaunas, who have found that the use of white spirit on finely milled chalk samples for releasing foraminifera from the Chalk Group is far more effective than the use of disaggregants such as $\left(\mathrm{NaPO}_{3}\right)_{6}$ (I. P. Wilkinson, personal communication, 2002).

\section{The Upper Cretaceous of Bodman Point, Seymour Island, Antarctica (both preparation methods, quantitative)}

Six samples of the Upper Cretaceous part of the López de Bertodano Formation (Marambio Group) from Bodman Point, Seymour Island, Antarctica were studied (Figure 5). All the samples were prepared quantitatively using the mineral acid procedure and $\left(\mathrm{NaPO}_{3}\right)_{6}$. The quantitative method was used in order to test whether the two preparation techniques yield the same levels of palynomorphs per gram of rock in an unlithified, siliciclastic succcession. The samples are listed in Appendix 1 and the results tabulated as Table 4. The samples studied are of Maastrichtian age on the basis of strontium isotope stratigraphy and evidence from belemnites and palynomorphs. The López de Bertodano Formation is a thick succession of largely unlithified silty sands and clays, representing a range of shallow marine shelf environments (Macellari, 1988; Zinsmeister et al., 1989; Pirrie et al., 1991; Crame et al., 1991). The James Ross Basin has not been buried, hence the extensive Cretaceous and Palaeogene back arc basin succession is largely unlithified (Crame et al., 1991).

The samples all proved organically productive, with prominent wood fragments, plant tissues and palynomorphs. The palynomorph assemblages proved to be similar in terms of both species and relative proportions of species, the conservative nature of the floras indicating deposition in a stable marine palaeoenvironment within a single genetic sedimentary sequence. Pollen grains are the dominant element, being more abundant than spores, dinoflagellate cysts and acritarchs. The pollen associations include bisaccate grains, Microcachryidites antarcticus, Nothofagidites spp., Peninsulapollis gillii, Peninsulapollis truswelliae, Phyllocladidites mawsonii, Polycolpites langstonii, Propylipollis sp. and Proteacidites spp. Cryptogam spores include Ceratosporites equalis, Cyathidites spp., Grapnelispora sp., Laevigatosporites spp., Perotriletes majus and Retitriletes austroclavatidites. The dinoflagellate cysts recovered include Alterbidinium acutulum, Batiacasphaera spp., Cribroperidinium spp., Exochosphaeridium sp., Impagidinium sp., Isabelidinium spp. (Figure 3Q). Manumiella seymourensis, Manumiella spp., 
Octodinium askiniae and Palaeocystodinium spp. The dinoflagellate cyst assemblage indicates an early-mid Maastrichtian age (Askin, 1988).

The two styles of preparation of all six samples produced generally similar organic residues and palynofloras (Table 4). For example, the numbers of palynomorphs per gram in sample 34 are extremely close (Table 4). It is clear, however, that the $\left(\mathrm{NaPO}_{3}\right)_{6}$ preparations are normally significantly palynologically richer than their counterparts prepared using acids. The mineral acid method only produced more palynomorphs per gram in sample 32 . The difference in the two yields are highly significant at this horizon; the $\left(\mathrm{NaPO}_{3}\right)_{6}$ preparation yielded only $55.9 \%$ of the palynomorphs produced using the acid method (Table 4 ). The two preparations of sample 31 appear visually to be virtually identical, although the $\left(\mathrm{NaPO}_{3}\right)_{6}$ preparation is clearly richer (Table 4). This situation also pertains to the remaining samples $35,34,33$ and 30 , and this difference in richness is clear from even a cursory examination of these slides. In samples 34 and 33, the acid preparations have more extraneous material than the $\left(\mathrm{NaPO}_{3}\right)_{6}$ slides. The three palynomorph groups differentiated in Table 4, miospores, dinoflagellate cysts and various microplankton, are consistently present in similar proportions. This strongly suggests that neither of the two preparation methods affect one palynomorph group more than another. These samples prove that the $\left(\mathrm{NaPO}_{3}\right)_{6}$ preparation method is suitable for samples of unlithified clays, silts and sands. Furthermore, in most cases, the $\left(\mathrm{NaPO}_{3}\right)_{6}$ preparations are richer and cleaner than samples prepared using mineral acids.

\section{The Quaternary of the UK}

Because of the generally unlithified nature of Quaternary sediments, the $\left(\mathrm{NaPO}_{3}\right)_{6}$ preparation method has proved extremely effective on samples of this age. Three examples from the Quaternary of the UK are described in this section.

5.1 Devensian till from the Commonwealth Games Stadium site, Manchester (both preparation methods, quanti-
tative).Two samples of Devensian till from the site of the 2002 Commonwealth Games Stadium in Manchester, northwest England (Figure 2), were prepared quantitatively using both mineral acids and $\left(\mathrm{NaPO}_{3}\right)_{6}$. This sediment is a brown, clay-rich till with abundant erratic clasts; similar sediment blankets much of the Pennine Plateau of northern England. Both methods produced closely similar organic residues and palynomorph associations. The two till samples yielded residues dominated by dark brown/black wood fragments and well-preserved Late Carboniferous (Westphalian) spore assemblages. Other plant tissues are also present, but in lower proportions. Pollen and spores of Quaternary aspect are relatively sparse. Polypodium spores are present persistently and arboreal pollen is, by contrast, rare; a single specimen of Tilia was recorded from sample 36. Minor levels of the freshwater/brackish alga Botryococcus braunii were also noted. Resistant mineral grains and amorphous organic material are absent. Densosporites spp. and Lycospora pusilla (Figure 3L) overwhelmingly dominate the Carboniferous spore associations. Associated with these are forms such as Cirratriradites saturni, Crassispora kosankei, Cristatisporites indignabundus, Dictyotriletes bireticulatus, Endosporites globiformis, Florinites spp., Knoxisporites spp., Potonieisporites spp., Radiizonates aligerens, Raistrickia fulva, Savitrisporites spp., Triquitrites spp and Vestispora sp. This flora is indicative of the Westphalian Series (Smith \& Butterworth, 1967; Clayton et al., 1977). The dominance of Westphalian spores indicates that much of the material incorporated into the till was derived from the nearby Lancashire and Yorkshire coalfields.

The preparations were closely comparable in terms of preservation levels, relative proportions, and diversities of both palynomorphs and kerogen macerals (Figure 6A). Counts of palynomorphs per gram, however, indicate that palynomorph recovery is markedly higher in the samples prepared using $\left(\mathrm{NaPO}_{3}\right)_{6}$ (Table 5). The samples prepared using mineral acid digestion proved remarkably similar in terms of numbers of palynomorphs per gram of sediment. In the acid preparations, the proportion of Carboniferous spores is

Table 4. Numbers of palynomorphs per gram from samples 35 to 30 of the López de Bertodano Formation, Seymour Island, Antarctica, prepared quantitatively using both methods. The largest within the respective pairs of figures are emboldened. The two right hand columns are a comparison between the two methods: these comprise the number of grains per slide from the acid method, minus this figure for the $\left(\mathrm{NaPO}_{3}\right)_{6}$ procedure (Difference in number), and the percentage of this difference with respect to the overall count (Difference in \%) for both methods respectively. Where the $\left(\mathrm{NaPO}_{3}\right)_{6}$ preparation method has produced a higher number of palynomorphs per gram, these figures are emboldened. Abbreviations: D, dinoflagellate cysts; M, miospores; P, Palynomorphs; V, various microplankton.

\begin{tabular}{c|c|c|c|c|c|c|c|c|c|c} 
Sample & \multicolumn{4}{|c|}{ Mineral Acid preparation } & \multicolumn{3}{c|}{ Sodium hexametaphosphate } & Difference & Difference \\
\# & $\mathbf{P}$ & $\mathbf{M}$ & $\mathbf{D}$ & $\mathbf{V}$ & $\mathbf{P}$ & $\mathbf{M}$ & $\mathbf{D}$ & $\mathbf{V}$ & in number & in \% \\
\hline $\mathbf{3 0}$ & 4577 & 4087 & 469 & $\mathbf{1 2 1}$ & $\mathbf{5 9 4 1}$ & $\mathbf{5 3 4 5}$ & $\mathbf{5 4 3}$ & 53 & $\mathbf{- 1 3 6 4}$ & $\mathbf{1 2 , 9 7 \%}$ \\
$\mathbf{3 1}$ & 3167 & 2419 & $\mathbf{4 1 2}$ & $\mathbf{3 3 6}$ & $\mathbf{3 8 4 9}$ & $\mathbf{3 2 5 5}$ & 356 & 238 & $\mathbf{- 6 8 2}$ & $\mathbf{9 , 7 2 \%}$ \\
$\mathbf{3 2}$ & $\mathbf{4 4 0 9}$ & $\mathbf{3 7 2 3}$ & $\mathbf{4 1 1}$ & $\mathbf{2 7 5}$ & 2465 & 2173 & 169 & 123 & +1944 & $\mathbf{2 8 , 2 8 \%}$ \\
$\mathbf{3 3}$ & 3837 & 3241 & 336 & $\mathbf{2 6 0}$ & $\mathbf{4 1 8 6}$ & $\mathbf{3 6 5 8}$ & $\mathbf{3 6 8}$ & 160 & $\mathbf{- 3 4 9}$ & $\mathbf{4 , 3 5 \%}$ \\
$\mathbf{3 4}$ & 3981 & $\mathbf{3 3 6 9}$ & 358 & $\mathbf{2 5 4}$ & $\mathbf{4 0 2 7}$ & 3325 & $\mathbf{5 1 8}$ & 184 & $\mathbf{- 4 6}$ & $\mathbf{0 , 5 7 \%}$ \\
$\mathbf{3 5}$ & $\mathbf{3 3 8 7}$ & 2869 & 320 & 198 & $\mathbf{3 9 2 3}$ & $\mathbf{3 3 4 7}$ & $\mathbf{3 5 3}$ & $\mathbf{2 2 3}$ & $\mathbf{- 5 3 6}$ & $\mathbf{7 , 3 3 \%}$ \\
\hline
\end{tabular}


Table 5. Numbers of palynomorphs per gram from samples 37 and 36 from the Pennine Plateau near Manchester, which were prepared quantitatively using both methods. The largest within the respective pairs of figures are emboldened. The two right hand columns are a comparison between the two methods: these comprise the number of grains per gram from the acid method, minus this figure for the $\left(\mathrm{NaPO}_{3}\right)_{6}$ procedure (Difference in number), and the percentage of this difference with respect to the overall count (Difference in \%) for both methods respectively. Where the $\left(\mathrm{NaPO}_{3}\right)_{6}$ preparation method has produced a higher number of palynomorphs per gram, these figures are emboldened. Abbreviations: B, Botryococcus; C, Carboniferous miospores; P, Palynomorphs; Q, Quaternary pollen and spores.

\begin{tabular}{c|c|c|c|c|c|c|c|c|c|c} 
Sample & \multicolumn{4}{|c|}{ Mineral Acid } & \multicolumn{3}{c|}{ Sodium hexametaphosphate } & Difference & Difference \\
\cline { 2 - 9 }$\#$ & $\mathbf{P}$ & C & Q & B & P & C & Q & B & in number & in \% \\
\hline 36 & 4795 & 4527 & 251 & $\mathbf{1 7}$ & $\mathbf{6 5 4 9}$ & $\mathbf{6 1 2 9}$ & $\mathbf{4 0 9}$ & 11 & $-\mathbf{1 7 5 4}$ & $\mathbf{1 5 , 4 6 \%}$ \\
$\mathbf{3 7}$ & 4782 & 4688 & 87 & 7 & $\mathbf{8 7 6 5}$ & $\mathbf{8 6 1 3}$ & $\mathbf{1 3 9}$ & $\mathbf{1 3}$ & $\mathbf{- 3 9 8 3}$ & $\mathbf{2 9 , 4 0 \%}$ \\
\hline
\end{tabular}

slightly higher in sample 37 . The concentration of Botryococcus braunii in sample 36 is higher in the acid preparation. This is the only category where the acid technique gives a higher proportion than the $\left(\mathrm{NaPO}_{3}\right)_{6}$ method. Sample 37 prepared using $\left(\mathrm{NaPO}_{3}\right)_{6}$ proved significantly richer than sample 36. The major part of this difference represents more Carboniferous spores, however sample 36 has fewer Quaternary pollen and spores than sample 37 (Table 5). These results confirm that the $\left(\mathrm{NaPO}_{3}\right)_{6}$ method is ideal for the preparation of clay-rich, unconsolidated, glaciogenic sediments.

5.2 Chalky diamicton from the BGS Britons Lane Borehole, north Norfolk (sodium hexametaphosphate method only, non-quantitative). Two samples of highly chalky diamictons from the BGS Britons Lane Borehole, north Norfolk, southeast England (Figure 2) were prepared non-quantitatively using the $\left(\mathrm{NaPO}_{3}\right)_{6}$ method only. This borehole was drilled in a quarry near Beeston Regis, west of Sheringham (TG 168 415); an account of the palynology of the diamicton units penetrated to $32.00 \mathrm{~m}$ was given by Riding (2002b). Samples 39 and 38 at $22.50-22.95 \mathrm{~m}$ and $16.90-17.00 \mathrm{~m}$ respectively, both produced extremely rich palynofloras that, unsurprisingly, are dominated by diverse and well-preserved Late Cretaceous dinoflagellate cysts (Figures 3M-3P, 3R; 6B, $6 \mathrm{D})$. This clearly is a reflection of the obvious chalk-rich nature of this unit and the palynomorph associations from samples 39 and 38 were found to comprise $99.3 \%$ and $98.7 \%$ Chalk Group dinoflagellate cysts respectively. The two intervals sampled were prodigiously productive and yielded 21879 and 18813 palynomorphs per microscope slide, with minor levels of Carboniferous, Jurassic and Quaternary palynomorphs. The Chalk Group dinoflagellate cyst flora is interpreted as being latest Campanian to early Maastrichtian in age, based on the occurrences of key taxa such as Alisocysta circumtabulata, Cannosphaeropsis utinensis, Cladopyxidium paucireticulatum, Gillinia hymenophora, Hystrichosphaeropsis quasicribrata, Isabelidinium cooksoniae, Neoeurysphaeridium glabrum, Neonorthidium perforatum, Palaeotetradinium maastrichtiense, Spongodinium delitiense, Wilsonisphaera petila and Xenascus "wetzelii" of Slimani (1996). This is based on the European stratigraphical accounts of, for example, Wilson (1974), Foucher (1979), Foucher in Robaszynski et al. (1985), Herngreen et al. (1986) and Slimani $(1994,1996)$.
There appears to have been no discernible mixing of the Chalk Group input into this diamicton and proves that the Chalk Group input is entirely from the White Chalk Subgroup and was therefore locally derived. The dinoflagellate cyst associations are extremely similar in composition and relative proportions to those from the Upper Campanian and Lower Maastrichtian of the Trunch Borehole (see section 3), which supports a local origin for the Chalk in this diamicton. Other chalky diamictons from north Norfolk have yielded similar Campanian and Maastrichtian markers (Riding, 2002c). The abundance, diversity and well-preserved nature of these largely Late Cretaceous palynofloras from the Britons Lane Borehole highly chalky diamictons indicates that the $\left(\mathrm{NaPO}_{3}\right)_{6}$ preparation technique is ideal for calcareous glaciogenic material. It was noted in section 3 that the $\mathrm{HCl}$ preparation method was more effective than the $\left(\mathrm{NaPO}_{3}\right)_{6}$ technique for White Chalk Subgroup samples (Figures 6B, 6D). In these two diamicton samples, however, the $\left(\mathrm{NaPO}_{3}\right)_{6}$ method yielded highly abundant, very well-preserved palynomorphs. The $\left(\mathrm{NaPO}_{3}\right)_{6}$ preparations closely resemble those prepared using $\mathrm{HCl}$ from the Trunch Borehole. The reason for this apparent anomaly is not known. It is possible that the Chalk here is more marly, or it was partially disaggregated during glaciogenic processes, thereby making it more suitable for the $\left(\mathrm{NaPO}_{3}\right)_{6}$ processing method. This contention should be tested by using both preparation methods quantitatively on these chalky diamictons.

5.3 Quaternary sediments from the Hebridean Slope (sodium hexametaphosphate method only, non-quantitative). Three Quaternary samples of brown/black clay were studied from BGS offshore shallow borehole number 56-10/249 CS, located west of the Hebrides $\left(56^{\circ} 14.53^{\prime} \mathrm{N} 009^{\circ} 13.95^{\prime} \mathrm{W}\right)$, between 2.41 and $0.50 \mathrm{~m}$ (Figure 7). They were prepared nonquantitatively using the $\left(\mathrm{NaPO}_{3}\right)_{6}$ method only. This borehole was drilled as part of an assessment of offshore slope stability and a more comprehensive account of the palynology was given by Riding (2002d). All three samples proved rich in indigenous and reworked palynomorphs. The indigenous Quaternary dinoflagellate cyst floras are overwhelmingly dominated by Brigantedinium spp., including B. simplex (Figures 3I, 3J; 6C). Other taxa present include Achomosphaera andalousiensis, Bitectatodinium tepikiense, Operculodinium centrocarpum and Spiniferites spp. These low diversity associations, dominated by protoperidinioid 

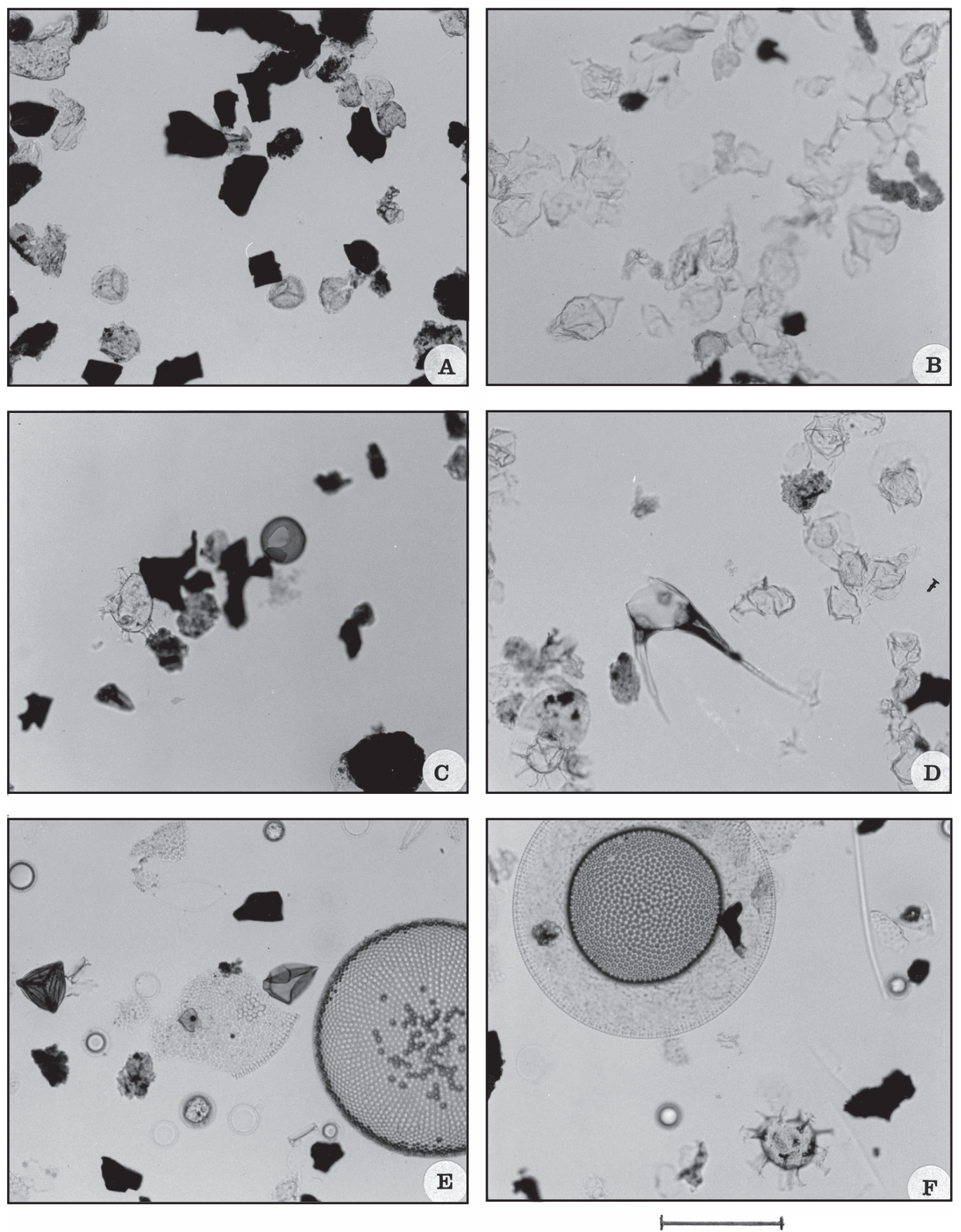

Figure 6. Examples of palynological preparations using the sodium hexametaphosphate ('hexa') procedure. Scale bar = $100 \mu$ m. A. Commonwealth Games Stadium site, Manchester, Upper Pleistocene Till. Sample 36, 'hexa' slide MPA 51063/2, R52/2. Note the abundant wood fragments and miospores; B. BGS Britons Lane Borehole, Quaternary diamicton. Sample 39, 'hexa' slide MPA 50997/2, P56/4. Note the abundant dinoflagellate cysts; C. BGS offshore borehole 56-10/249 CS, Quaternary brown/black clay. Sample 40, 'hexa' slide MPA 50819/1, G64. Note the common dinoflagellate cysts; D. Location/stratigraphical details as B. Sample 38, 'hexa' slide MPA 50994/1, P47. Note the abundant dinoflagellate cysts; E, F. BGS offshore borehole 56-10/255 VE, Quaternary brown/black clay at $3.44 \mathrm{~m}-3.47 \mathrm{~m}$. Sample MPA 50832, 'hexa' slide 1, J48/4 (E) and S59/2 (F). This borehole cored a similar succession to borehole 56-10/249 CS and is located nearby, at $56^{\circ} 22.15^{\prime} \mathrm{N} 009^{\circ} 10.11^{\prime} \mathrm{W}$. These two photomicrographs are included in order to demonstrate that the sodium hexametaphosphate preparation technique is suitable for both palynomorphs and silicofossils. Both photomicrographs include both these microfossil types. Note the reworked Cretaceous spore Cicatricosisporites in $\mathrm{E}$ and the chorate dinoflagellate cyst in $\mathrm{F}$; note also the abundant pennate and centric diatoms in both photomicrographs. 
cysts, are indicative of a relatively nearshore, glacial environment with seasonal or permanent sea-ice. The presence of Brigantedinium simplex is indicative of a Mid Pleistocene or younger age (Harland, 1992). The palynomorph content of the three samples proved relatively constant and the succession appears to be part of the same genetic sequence. Carboniferous, Jurassic, Cretaceous and Palaeogene reworking was also observed throughout (Figure 3K). Much of the Carboniferous reworking is likely to be Westphalian due to the presence in sample 41 of Endosporites globiformis (see Smith \& Butterworth, 1967). The typically Bathonian to early Callovian (Mid Jurassic) dinoflagellate cyst Ctenidodinium combazii was also present in sample 41. Nannoceratopsis pellucida was recovered in sample 42 ; this Jurassic dinoflagellate cyst is typical of the Bathonian to Oxfordian interval (Riding \& Thomas, 1992). The high abundance and well-preserved nature of these indigenous and allochthonous palynofloras from this succession indicates that the $\left(\mathrm{NaPO}_{3}\right)_{6}$ technique is eminently suitable for unconsolidated clay samples (Figure 6C).

Marine Quaternary samples may be rich in silicofossils and the $\left(\mathrm{NaPO}_{3}\right)_{6}$ preparation technique is also effective for preparing diatoms, radiolaria and silicoflagellates. A section drilled close to this borehole has yielded Quaternary clays that are rich in both silicofossils and palynomorphs. This is BGS borehole number 56-10/255 VE $\left(56^{\circ} 22.15^{\prime} \mathrm{N} 009^{\circ} 10.11^{\prime} \mathrm{W}\right)$, which cored a similar succession to borehole 56-10/249 CS. Preparations of these sediments comprise a mixture of palynomorphs and silicofossils (Figures 6E, 6F). The dual function of the $\left(\mathrm{NaPO}_{3}\right)_{6}$ preparation method is another major advantage of this technique.

\section{CONCLUSIONS}

The development of the palynological preparation method using $\left(\mathrm{NaPO}_{3}\right)_{6}$, and its demonstration using seven case studies has shown that viable alternatives to the hazardous, time-consuming and expensive mineral acid technique can be developed. It seems clear that sediment/ rock disaggregation, coupled with density separation methods, can extract palynomorphs effectively. Furthermore, any procedure that bypasses a complex chemical process using highly aggressive reagents should theoretically yield palynomorph assemblages that are closest to the material preserved. This is especially important as the majority of modern palynological studies are based on quantitative data.
The traditional mineral acid procedure involves many stages, any of which could damage palynomorphs. The $\left(\mathrm{NaPO}_{3}\right)_{6}$ technique appears to work on most of the lithologies tested. Of the five case studies where both methods were used, the $\left(\mathrm{NaPO}_{3}\right)_{6}$ method was not as effective as the acid procedure in only one situation, the Chalk Group of north Norfolk. More studies should be done using $\left(\mathrm{NaPO}_{3}\right)_{6}$ to prove its effectiveness in other lithologies and further develop this technique. For example, the $\left(\mathrm{NaPO}_{3}\right)_{6}$ technique needs testing on pre-Jurassic samples, sandstones, highly indurated mudstones and more organic-rich sedimentary rocks. It is hoped that this contribution will stimulate further experimentation on palynological techniques, leading to the discovery of additional safer preparation procedures.

\section{ACKNOWLEDGEMENTS}

This work was done as part of the British Geological Survey (BGS) 'Development of Capability' programme. Both authors publish with the permission of the Executive Director, British Geological Survey (NERC). The support of this project given by John H. Powell (BGS) and Dermeval Aparecido do Carmo (University of Brasília, Brasil) is greatly appreciated. This contribution has benefited greatly from thorough and perceptive critical reviews from Sarah R. de la Rue (Louisiana State University, USA), Stewart G. Molyneux (BGS) and 
Michael H. Stephenson (BGS). Michael H. Stephenson also kindly identified some of the Carboniferous spore taxa in the two Devensian Till samples from the Commonwealth Games Stadium, which were provided by Holger Kessler (BGS). The samples from the Hebridean margin borehole 56-10/249 CS were made available through the BGS Western Frontiers Association. Nilda Maria Diniz and Dermeval Aparecido do Carmo (University of Brasília, Brasil) kindly translated the English abstract into Portugese.

\section{REFERENCES}

Aldridge, R.J. 1990. Extraction of microfossils. In: D.E.G. Briggs \& P.R.Crowther (eds.) Palaeobiology - A synthesis. Blackwell Scientific Publications, Oxford, p.502-504.

Andersen, S.T. 1960. Silicone oil as a mounting medium for pollen grains. Danmarks Geologiske Undersфgelse, IV Raekke, 4(1):24 p.

Arms, B.C. 1960. A silica depressant method for concentrating fossil pollen and spores. Micropaleontology, 6:327-328.

Artusy, R.L. \& Artusy, J.C. 1956. The use of food coloring as a new technique for staining microfossils. Journal of Paleontology, 30:969-970.

Askin, R.A. 1988. Campanian to Paleocene palynological succession of Seymour and adjacent islands, northeastern Antarctic Peninsula. In: R.M. Feldmann \& M.O. Woodburne (eds.) Geology and paleontology of Seymour Island, Antarctic Peninsula. Geological Society of America, p:131-153 (Memoir 169).

Assarson, G. \& Granlund, E. 1924. En metod för pollenanalys av minerogena jordater. Geologiska Föreningens $i$ Stockholm Förhandlingar, 46:76-82.

Barss, M.S. \& Crilley, B. 1976. A mounting medium for palynological residues. Geological Survey of Canada Paper, 76 (1B): 132-133.

Barss, M.S. \& Williams, G.L. 1973. Palynology and nannofossil processing techniques. Geological Survey of Canada Paper, No. 73-26:iv + 25 p.

Bates, C.D.; Coxon, P. \& Gibbard, P.L. 1978. A new method for the preparation of clay-rich sediment samples for palynological analysis. New Phytologist, 81:459-463.

Batten, D. J. 1999. 4. Small palynomorphs. In: T.P. Jones \& N.P. Rowe (eds.) Fossil plants and spores: modern techniques. Geological Society, London, p.15-19.

Batten, D.J., \& Morrison, L. 1983. Methods of palynological preparation for palaeoenvironmental, source potential and organic maturation studies. In: L.I. Costa (ed.) Palynology Micropalaeontology: Laboratories, Equipment and Methods. Norwegian Petroleum Directorate Bulletin, 2:35-53.

Bigelow, J.H. 1980. Improved palynographic technique. Micropaleontology, 26:193-195.

Björck, S.; Persson, T. \& Kristersson, I. 1978. Comparison of two concentration methods for pollen in minerogenic sediments. Geologiska Föreningens $i$ Stockholm Förhandlingar, 100:107-111.

Bodine, M.W. Jr. \& Fernalld, T.H. 1973. EDTA dissolution of gypsum, anhydrite, and $\mathrm{Ca}-\mathrm{Mg}$ carbonates. Journal of Sedimentary Petrology, 43:1152-1156.

Bond, T.A. 1964. Removal of colloidal material from palynological preparations. Oklahoma Geology Notes, 24:212-213.
Bostick, N.H. 1971. Thermal alteration of clastic organic particles as an indicator of contact and burial metamorphism in sedimentary rocks. Geoscience and Man, 3:83-92.

Brasier, M.D. 1980. Microfossils. George Allen and Unwin, London, 193 p.

Bristow, C.R.; Mortimore, R.N. \& Wood, C.J. 1997. Lithostratigraphy for mapping the Chalk of southern England. Proceedings of the Geologists' Association, 108:293-315.

Brooks, J.; Grant, P.R.; Muir, M.; Van Gijzel, P. \& Shaw, G. (eds.) Sporopollenin. Proceedings of a Symposium held at the Geology Department, Imperial College, London, 23 $3^{\text {rd }}-25^{\text {th }}$ September, 1970. Academic Press, London, 718 p.

Brooks, J. \& Shaw, G. 1968a. The post-tetrad ontogeny of the pollen wall and the chemical structure of the sporopollenin of Lilium henryi. Grana, 8:227-234.

Brooks, J. \& Shaw, G. 1968b. Identity of sporopollenin with older kerogen and new evidence for the possible biological source of chemicals in sedimentary rocks. Nature, 220:678682.

Brooks, J. \& Shaw, G. 1972. Geochemistry of sporopollenin. Chemical Geology, 10:69-87.

Brooks, J. \& Shaw, G. 1978. Sporopollenin: a review of its chemistry, palaeochemistry and geochemistry. Grana, 17:9197.

Brown, C.A. 1960. Palynological Techniques. Privately published, Baton Rouge, Louisiana, USA; 188 p.

Bucefalo Palliani, R.; Mattioli, E. \& Riding, J.B. 2002. The response of marine phytoplankton and sedimentary organic matter to the early Toarcian (Lower Jurassic) oceanic anoxic event in northern England. Marine Micropaleontology, 46:223245.

Bucefalo Palliani, R. \& Riding, J.B. 1999. Relationships between the early Toarcian anoxic event and organic-walled phytoplankton in central Italy. Marine Micropaleontology, 37:101-116.

Bucefalo Palliani, R. \& Riding, J.B. 2000. A palynological investigation of the Lower and lowermost Middle Jurassic strata (Sinemurian to Aalenian) from North Yorkshire, UK. Proceedings of the Yorkshire Geological Society, 53:116.

Bucefalo Palliani, R. \& Riding, J.B. 2003. Biostratigraphy, provincialism and evolution of European Early Jurassic (Pliensbachian to early Toarcian) dinoflagellate cysts. Palynology, 27:179-214.

Bujak, J.P.; Downie, C.; Eaton, G.L. \& Williams, G.L. 1980. Dinoflagellate cysts and acritarchs from the Eocene of southern England. Special Papers in Palaeontology, 24:1-100 .

Campbell, I.D. 1991. Experimental mechanical destruction of pollen grains. Palynology, 15:29-33.

Campbell, I.D. \& Campbell, S. 1994. Pollen preservation: experimental wet-dry cycles in saline and desalinated sediments. Palynology, 18:5-10.

Caratini, C. 1980. Ultrasonic sieving to improve palynological processing of sediments: a new device. International Commission for Palynology Newsletter, 3(1):4.

Clarke, C.M. 1994. Differential recovery of fungal and algal palynomorphs versus embryophyte pollen and spores by three processing techniques. In: O.K. Davis (ed.) Aspects of archaeological palynology: methodology and applications. American Association of Stratigraphic Palynologists, p. 5362 (Contributions Series 29). 
Clarke, R.T. 1963. Elimination of bleeding of Safranine O stain in Clearcol. Oklahoma Geology Notes, 23:259.

Clay-Poole, S.T. 1990. Calcium dissolution and clay flocculant removal in pollen extractions from sediments of the arid southwest, USA. Journal of Paleontology, 64:483-484.

Clayton, G.; Coquel, R.; Doubinger, J.; Gueinn, K.J.; Loboziak, S.; Owens, B. \& Streel, M. 1977. Carboniferous miospores of Western Europe: illustration and zonation. Mededelingen Rijks Geologische Dienst, 29:1-71.

Clements, R.G. 1989. Tailor-made geology 4: Brown's Hill Quarry, Holwell, Leicestershire. Geology Today, JanuaryFebruary 1989:28-30.

Colbath, G.K. 1985. A comparison of palynological extraction techniques using samples from the Silurian Bainbridge Formation, Missouri, U.S.A. Review of Palaeobotany and Palynology, 44:153-164.

Cookson, I.C. \& Hughes, N.F. 1964. Microplankton from the Cambridge Greensand (mid-Cretaceous). Palaeontology, 7:3759.

Costa, L.I. 1983. Safety in palynology laboratories. In: Costa, L.I. (ed.) Palynology - Micropalaeontology: Laboratories, Equipment and Methods. Norwegian Petroleum Directorate Bulletin, 2:75-84.

Crame, J.A.; Pirrie, D.; Riding, J.B. \& Thomson, M.R.A. 1991. Campanian-Maastrichtian (Cretaceous) stratigraphy of the James Ross Island area, Antarctica. Journal of the Geological Society, London, 148:1125-1140.

Cridland, A.A. 1966. An apparatus for hydrofluoric acid macerations. Micropaleontology, 12:510.

Cwynar, L.C.; Burden, E. \& McAndrews, J.H. 1979. An inexpensive sieving method for concentrating pollen and spores from fine-grained sediments. Canadian Journal of Earth Sciences, 16:1115-1120.

Dale, B. 1976. Cyst formation, sedimentation, and preservation: factors affecting dinoflagellate assemblages in Recent sediments from Trondheimsfjord, Norway. Review of Palaeobotany and Palynology, 22:39-60.

Davey, R.J. \& Verdier, J.-P. 1971. An investigation of microplankton assemblages from the Albian of the Paris Basin. Verhandelingen der Koninklijke Nederlandsche Akademie van Wetenschappen, Afdeling Natuurkunde, Eerste Reeks, 26,58 p.

Davey, R.J. \& Verdier, J.-P. 1973. An investigation of microplankton assemblages from latest Albian (Vraconian) sediments. Revista Española de Micropaleontología, 5:173212.

Davis, P. 1961. Use of stannic chloride for heavy-liquid flotation of palynological fossils. Oklahoma Geology Notes, 21:259260.

Deflandre, G. 1936. Microfossiles des silex crétacés. Première partie. Généralités. Flagellés. Annales de Paléontologie, 25:151-191.

Deflandre, G. 1937. Microfossiles des silex crétacés. Deuxième partie. Flagellés incertae sedis. Hystrichosphaeridés. Sarcodinés. Organismes divers. Annales de Paléontologie, 26:51-103.

Dempsey, J.E. \& Urban, L.L. 1965. Dry storage of processed palynological residues. Pollen et Spores, 7:577-579.

Dodson, J.R. 1983. Pollen recovered from organic lake clays: a comparison of two techniques. Pollen et Spores, 25:131-138.
Dodsworth, P. 1995. A note of caution concerning the application of quantitative palynological data from oxidized preparations. Journal of Micropalaeontology, 14:6.

Doher, L.I. 1980. Palynomorph preparation procedures currently used in the paleontology and stratigraphy laboratories, U.S. Geological Survey, U.S. Geological Survey, 29 p. (Circular 830).

Downie, C. 1959. Hystrichospheres from the Silurian Wenlock Shale of England. Palaeontology, 2:56-71.

Eagar, S.H. \& Sarjeant, W.A.S. 1963. Fossil hystrichospheres concentrated by sieving techniques. Nature, 198:81.

Eaton, G.L. 1976. Dinoflagellate cysts from the Bracklesham Beds (Eocene) of the Isle of Wight, southern England. Bulletin of the British Museum (Natural History) Geology, 26(6):227332.

Echols, D.J. \& Levin, H.L. 1964. Chalk crayons and microfossil contamination. Micropaleontology, 10:80.

Ediger, V.S. 1986. Sieving techniques in palynological sample processing with special reference to the MRA system. Micropaleontology, 32:256-270.

Ehrenberg, C.G. 1838. Über das Massenverhältniss der jetzt lebenden Kiesel-Infusorien und über ein neues InfusorienConglomerat als Polierschiefer von Jastraba in Ungarn. Königlich Akademie der Wissenschaften zu Berlin Abhandlungen 1836, 1:109-135.

Ellin, S. \& McLean, D. 1994. The use of microwave heating in hydrofluoric acid digestions for palynological preparations. Palynology, 18:23-31.

Elsik, W.C. 1966a. Biologic degradation of fossil pollen grains and spores. Micropaleontology, 12:515-518.

Elsik, W.C. 1966b. Degradation of arci in a fossil Alnus pollen grain. Nature, 209:825.

Erdtman, G. 1936. New methods in pollen analysis. Svensk Botanisk Tidskrift, 30:154-164.

Erdtman, G. 1960. The acetolysis method. Svensk Botanisk Tidskrift, 54:561.

Eshet, Y. \& Hoek, R. 1996. Palynological processing of organicrich rocks, or: How many times have you called a palyniferous sample "barren". Review of Palaeobotany and Palynology, 94:101-109.

Evitt, W.R. 1984. Some techniques for preparing, manipulating and mounting dinoflagellates. Journal of Micropalaeontology, 3(2):11-18.

Faegri, K. \& Iversen, J. 1975. Textbook of Pollen Analysis. Munksgaard, Copenhagen, Denmark, 295 p.

Farley, M.B. 1988. Environmental variation, palynofloras and paleoecological interpretation. In: W.A. DiMichele \& S.L. Wing (eds.) Methods and applications of plant paleoecology. Paleontological Society Special Publication, 3:126-146.

Faruqi, S.A. \& Copley, A.J. 1966. A technique for separating pollen and spores from tar. Micropaleontology, 12:370.

Fawcett, P.; Green, D.; Holleyhead, R. \& Shaw, G. 1970. Application of radiochemical techniques to the determination of the hydroxyl content of some sporopollenins. Grana, 10:246-247.

Felix, C.J. 1963. Mechanical sample disaggregation in palynology. Micropaleontology, 9:337-339.

Felix, C.J. \& Burbridge, P. 1985. Reappraisal of a palynological storage technique. Pollen et Spores, 27:491-492. 
Fensome, R.A.; Taylor, F.J.R.; Norris, G.; Sarjeant, W.A.S.; Wharton, D.I. \& Williams, G.L. 1993. AMNH, A classification of living and fossil dinoflagellates. 351 p. (Micropaleontology Special Publication 7).

Fisher, J.C. 1962. Laboratory reagents as a possible cause of microfossil contamination. Micropaleontology, 8:508.

Flenley, J.R. 1971. Measurements of the specific gravity of the pollen exine. Pollen et Spores, 13:179-186.

Forster, M. \& Flenley, J.R. 1993. Pollen purification and fractionation by equilibrium density gradient centrifugation. Palynology, 17:137-155.

Foucher, J.-C. 1975. Dinoflagellés et acritarches des silex crétacés $\mathrm{du}$ Bassin de Paris: une synthèse stratigraphique. Annales scientifique de l'Université de Reims et de l'Association régionale pour l'étude et la recherche scientifiques (ARERS), 13:8-10.

Foucher, J.-C. 1979. Distribution stratigraphique des kystes de dinoflagellés et des acritarches dans le Crétacé supérieur du Bassin de Paris et de 1'Europe septentrionale. Palaeontographica Abteilung B, 169:78-105.

Frizzel, D.L. \& Middour, E.S. 1951. Paleocene Radiolaria from southeastern Missouri. University of Missouri School of Mines and Metallurgy, Technical Series, 41 p. (Bulletin 77).

Funkhouser, J.W. 1967. Factors that affect sample reliability. In: R. Tschudy \& R.T. Scott (eds.) Aspects of Palynology. WileyInterscience, p. 97-102.

Funkhouser, J.W. \& Evitt, W.R. 1959. Preparation techniques for acid-insoluble microfossils. Micropaleontology, 5:369-375.

Gray, J. 1965a. Palynological techniques. In: B. Kummel \& D. Raup (eds.) Handbook of Paleontological Techniques, W. H. Freeman and Company, p. 471-481.

Gray, J. 1965b. Techniques in palynology: extraction techniques. In: B. Kummel \& D. Raup (eds.) Handbook of Paleontological Techniques, W. H. Freeman and Company, p. 530-587.

Green, O.R. 2001. A manual of practical laboratory and field techniques in palaeobiology. Dordrecht, Kluwer Academic Publishers, $538 \mathrm{p}$.

Hallam, A. 1968. The Lias. In: P.C. Sylvester-Bradley \& T.D. Ford (eds.) The Geology of the East Midlands, Leicester University Press, p. 188-210.

Hancock, J.M. 1975. The petrology of the Chalk. Proceedings of the Geologists' Association, 86:499-535.

Hansen, J.M. \& Gudmundsson, L. 1979. A method for separating acid-insoluble microfossils from organic debris. Micropaleontology, 25:113-117.

Harland, R. 1989. A dinoflagellate cyst record for the last $0.7 \mathrm{Ma}$ from the Rockall Plateau, northeast Atlantic Ocean. Journal of the Geological Society, 146:945-951.

Harland, R. 1992. Dinoflagellate cysts of the Quaternary System. In: A.J. Powell (ed.) A stratigraphic index of dinoflagellate cysts, London, British Micropalaeontological Society Publications Series, Chapman and Hall, p. 253-273.

Hart, M.B. 1993. Cretaceous foraminiferal events. In: E.A. Hailwood \& R.B. Kidd (eds.) High resolution stratigraphy. Geological Society. p. 227-240 (Special Publication 70).

Havinga, A.J. 1964. Investigation into the differential corrosion susceptibility of pollen and spores. Pollen et Spores, 6:621635.

Havinga, A.J. 1967. Palynology and pollen preservation. Review of Palaeobotany and Palynology, 2:81-98.
Hay, W.W. 1977. Calcareous nannofossils. In: A.T.S. Ramsay (ed.) Oceanic Micropalaeontology. Academic Press, London, vol 2, p. 1055-1200.

Head, M.J. (ed.) 1995a. HF fatality. American Association of Stratigraphic Palynologists Newsletter, 28(1):14-15.

Head, M.J. (ed.) 1995b. Treatment of HF burns. American Association of Stratigraphic Palynologists Newsletter, 28(1): 15 .

Head, M.J. 1996. Chapter 30. Modern dinoflagellate cysts and their biological affinities. In: J. Jansonius \& D.C. McGregor (eds.) Palynology: principles and applications, American Association of Stratigraphic Palynologists Foundation, 3:1197-1248.

Health and Safety Executive 1999. COSHH, a brief guide to the regulations. UK Health and Safety Executive (HSE) Pamphlet, $20 \mathrm{p}$.

Herngreen, G.F.W. 1983. Palynological preparation techniques. In: L.I. Costa (ed.) Palynology - Micropalaeontology: Laboratories, Equipment and Methods. Norwegian Petroleum Directorate Bulletin, 2:13-34.

Herngreen, G.F.W.; Felder, W.M.; Kedves, M. \& Meessen, J.P.M.T. 1986. Micropaleontology of the Maestrichtian in borehole Bunde, the Netherlands. Review of Palaeobotany and Palynology, 48:1-70.

Heusser, L.E. 1983. Pollen distribution in the bottom sediments of the western North Atlantic Ocean. Marine Micropaleontology, 8:77-88.

Heusser, L.E. \& Stock, C.E. 1984. Preparation techniques for concentrating pollen from marine sediments and other sediments with low pollen density. Palynology, 8:225-227.

Higgins, A.C. \& and Spinner, E.G. 1969. Techniques for the extraction of selected microfossils. Geology - The Journal of the Association of Teachers in Geology, 1:12-28.

Hills, L.V. \& Sweet, A.R. 1972. The use of "Quaternary O" in megaspore palynological preparations. Review of Palaeobotany and Palynology, 13:229-231.

Hodgkinson, R.L. 1991. Microfossil processing: a damage report. Micropaleontology, 37:320-326.

Hoffmeister, W.S. 1960. Sodium hypochlorite, a new oxidizing agent for the preparation of microfossils. Oklahoma Geology Notes, 20:34-35 (Special Publication 152)

Holmes, N.A. 1999. The Andrew Formation and 'biosteering' different reservoirs, different approaches. In: R.W. Jones \& M.D. Simmons (eds.) Biostratigraphy in Production and Development Geology, Geological Society, p. 155-166.

Holst, G. 1954. The chemistry of bleaching and oxidizing agents. Chemical Reviews, 54:169-194.

Hopkins, J.A. \& McCarthy, F.M.G. 2002. Post-depositional palynomorph degradation in Quaternary shelf sediments: a laboratory experiment studying the effects of progressive oxidation. Palynology, 26:167-184.

Hughes, N.F.; De Jekowsky, B. \& Smith, A.H.V. 1964. Extraction of spores and other organic microfossils from Paleozoic clastic sediments and coals. Comptes Rendus Sixième Congrès International de Stratigraphie et de Géologie Carbonifère, 3:1095-1109.

Hyde, H.A. \& Williams, D.A 1944. The right word. Pollen Analysis Circular, 8:6.

Institute of Geological Sciences 1976. IGS Boreholes 1975. Report of the Institute of Geological Sciences, No. 76/10, 47 p. 
Ioannides, N.S.; Colin, J.-P. \& Jan du Chêne, R. 1988. A preliminary investigation of Kimmeridgian dinoflagellates and ostracodes from Quercy, southwest France. Bulletin des Centres de Recherches Exploration-Production Elf-Aquitaine, 12:471-491.

Ioannides, N.S.; Stavrinos, G.N. \& Downie, C. 1976. Kimmeridgian microplankton from Clavell's Hard, Dorset, England. Micropaleontology, 22:443-478.

Jackson, T.A.; Germs, A. \& Moorman, M. 1974. An improved method for the chemical maceration of sedimentary rocks. Journal of Paleontology, 48:844-845.

Jacobsen, S.R. \& Schopf, J.M. 1979. Preservation of palynological specimens examined by SEM for later microscopical study and reference. Journal of Paleontology, 53:744-746.

Jansonius, J. \& McGregor, D.C. (eds.) 1996a. Palynology: principles and applications. Dallas American Association of Stratigraphic Palynologists Foundation, 3 vols. 1330 p.

Jansonius, J. \& McGregor, D.C. 1996b. Chapter 1. Introduction. In: J. Jansonius \& D.C. McGregor (eds.) Palynology: principles and applications, Dallas, American Association of Stratigraphic Palynologists Foundation, Dallas, vol. 1, p. 110.

Jeffords, R.M. \& Jones, D.H. 1959. Preparation of slides for spores and other microfossils. Journal of Paleontology, 33:344350.

Johnson, W.C. \& Fredlund, G.G. 1985. A procedure for extracting palynomorphs (pollen and spores) from clastic sediments. Transactions of the Kansas Academy of Science, 88:51-58.

Jones, R.A. 1994. The application of microwave technology to the oxidation of kerogen for use in palynology. Review of Palaeobotany and Palynology, 80:333-338.

Jones, R.A. 1998. Focused microwave digestion and oxidation of palynological samples. Review of Palaeobotany and Palynology, 103:17-22.

Jones, R.A. \& Ellin, S.J. 1998. Improved palynological sample preparation using an automated focused microwave digestion system. In: V.M. Bryant \& J.H. Wrenn (eds.) New developments in palynomorph sampling, extraction, and analysis, American Association of Stratigraphic Palynologists, p. 23-28 (Contributions Series 33).

Juvigné, E. 1973a. Une méthode de séparation des pollens applicable aux sédiments minéraux. Annales de la Société Géologique de Belgique, 96:253-262.

Juvigné, E. 1973b. Densité des exines de quelques espèces de pollens et spores fossiles. Annales de la Société Géologique de Belgique, 96:363-374.

Kedves, M.J. 1985. Structural modification of degraded fossil sporomorphs. Micropaleontology, 31:175-180.

Kemp, E.M. 1970. Aptian and Albian miospores from southern England. Palaeontographica Abteilung B, 131:73-143.

Kempf, E.K. 1971. Elektronenmikroskopie der sporodermis von mega- und mikrosporen der Pteridophyten-gattung Salvinia aus dem Tertiär und Quartär Deutschlands. Palaeontographica Abteilung B, 136:47-70.

Kidson, E.J. \& Williams, G.L. 1969. Concentration of palynomorphs by use of sieves. Oklahoma Geology Notes, 29:117-119.

Killops, S.D. \& Killops, V.J. 1993. An introduction to organic chemistry. Wiley, New York, 265 p.

Knox, A.S. 1942. The use of bromoform in the separation of noncalcareous microfossils. Science, 95:307-308.
Kokinos, J.P.; Eglinton, T.I.; Goni, M.A.; Boon, J.J.; Martoglio, P.A. \& Anderson, D.M. 1998. Characterisation of a highly resistant biomacromolecular material in the cell wall of a marine dinoflagellate resting cyst. Organic Geochemistry, 28:265-288.

Kummel, B. \& Raup, D. (eds.) 1965. Handbook of Paleontological Techniques. San Francisco, W. H. Freeman and Company, $852 \mathrm{p}$.

Kurtz, E.B. Jr. \& Turner, R.M. 1957. An oil-flotation method for the recovery of pollen from inorganic sediments. Micropaleontology, 3:67-68.

Lee, H.W. 1964. A modified method of coal maceration and a simple technique for slide preparation. Micropaleontology, 10:486-490.

Lennie, C.R. 1968. Palynological techniques used in New Zealand. New Zealand Journal of Geology and Geophysics, 11:12111221.

Litwin, R.J. \& Traverse, A. 1989. Basic guidelines for palynomorph extraction and preparation from sedimentary rocks. In: R.M. Feldmann; R.E. Chapman \& J.T. Hannibal (eds.) Paleotechniques, The Paleontological Society Special Publication, 4, p. 87-98.

Macellari, C.E. 1988. Stratigraphy, sedimentology and paleoecology of Late Cretaceous/Paleocene shelf-deltaic sediments of Seymour Island, Antarctic Peninsula. In: R.M. Feldmann \& M.O. Woodburne (eds.) Geology and paleontology of Seymour Island, Antarctic Peninsula, Geological Society of America, p. 25-53 (Memoir 169).

Manskaya, S.M.; Kodina, L.A. \& Generalova, V.N. 1973. Chemical investigation of pollen and spore walls. Palynology in Medicine: 71-75 (In Russian with English summary).

Manum, S. 1956. Schulzes maserasjonsblanding. Et hundreårsminne. Blyttia, 14:126-130.

Marret, F. 1993. Les effets de l'acétolyse sur les assemblages des kystes de dinoflagellés. Palynosciences, 2:267-272.

Marshall, J.E.A. 1980. A method for the successful oxidation and subsequent stabilization of highly carbonized spore assemblages. Review of Palaeobotany and Palynology, 29:313319.

McCarthy, F.M.G.; Gostlin, K.E.; Mudie, P.J. \& Hopkins, J.A. 2002. Terrestrial and marine palynomorphs as sea-level proxies: an example from Quaternary sediments on the New Jersey margin. In: H.C. Olson \& M. Leckie (eds.) Micropaleontologic proxies for sea-level change and stratigraphic discontinuities, SEPM, p. 119-129 (Special Publication 75)

McIntyre, D.J. \& Norris, G. 1964. Effect of ultrasound on Recent spores and pollen. New Zealand Journal of Science, 7:242257.

McKee, K. 1977. A dialysis unit in palynological sample preparation. The British Micropalaeontologist, 5:12-13.

Moore, P.D.; Webb, J.A. \& Collinson, M.E. 1991. Pollen Analysis. 2 ed., Oxford, Blackwell Scientific Publications, 216 p.

Munsterman, D. \& Kerstholt, S. 1996. Sodium polytungstate, a new non-toxic alternative to bromoform in heavy liquid separation. Review of Palaeobotany and Palynology, 91:417422.

Nakagawa, T.; Brugiapaglia, E.; Digerfeldt, G.; Reille, M.; Beaulieu, J.-L. de \& Yasuda, Y. 1998. Dense-media separation as a more efficient pollen extraction method for use with organic sediment/deposit samples: comparison with the conventional method. Boreas, 27:15-24. 
Neves, R. \& Dale, B. 1963. A modified filtration system for palynological preparations. Nature, 4882:775-776.

Nøhr-Hansen, H. 1986. Dinocyst stratigraphy of the Lower Kimmeridge Clay, Westbury, Wiltshire, England. Bulletin of the Geological Society of Denmark, 35:31-51.

Nøhr-Hansen, H. 1993. Dinoflagellate cyst stratigraphy of the Barremian to Albian, Lower Cretaceous, North-East Greenland. Bulletin Grønlands Geologiske Undersøgelse, 166:1-171.

Norem, W.L. 1953. Separation of spores and pollen from siliceous rocks. Journal of Paleontology, 27:881-883.

Norem, W.L. 1956. An improved method for separating fossil spores and pollen from siliceous rocks. Journal of Paleontology, 30:1258-1274.

Nørgaard, I.; Rasmussen, A-M.; Schiøler, P. \& Stouge, S. 1991. A new method for bulk palynological processing of oilcontaminated chalks. Journal of Micropalaeontology, 10:202.

Oda, M.; Kitazato, H. \& Hasegawa, S. 1975. Some problems using sodium hexametaphosphate in treatment of rocks for microfossil analysis. Journal of the Japanese Association of Petroleum Technologists, 50:1-8.

Owen, H.G.; Shephard-Thorn, E.R. \& Sumbler, M.G. 1996. 6. Lower Cretaceous In: M.G. Sumbler. British Regional Geology: London and the Thames Valley, Her Majesty's Stationery Office for the British Geological Survey, p. 61-75.

Payne, S.N.J.; Ewen, D.F. \& Bowman, M.J. 1999. The role and value of 'high-impact biostratigraphy' in reservoir appraisal and development. In: R.W. Jones \& M.D. Simmons (eds.) Biostratigraphy in Production and Development Geology, Geological Society, p. 5-22 (Special Publication 152).

Peterson, S.; Maples, C.G. \& Lane, N. G. 1983. Use of surfactants in disaggregation of argillaceous rocks. Micropaleontology, 29:467-469.

Phipps, D. \& Playford, G. 1984. Laboratory techniques for extraction of palynomorphs from sediments. Papers of the Department of Geology, University of Queensland, 11: 1-23.

Pirrie, D.; Crame, J.A. \& Riding, J.B. 1991. Late Cretaceous stratigraphy and sedimentology of Cape Lamb, Vega Island, Antarctica. Cretaceous Research, 12:227-258.

Pirrie, D.; Marshall, J.D. \& Crame, J.A. 1998. Marine High Mg calcite cements in Teredolites-bored fossil wood; evidence for cool paleoclimates in the Eocene La Meseta Formation, Seymour Island, Antarctica. Palaios, 13:276-286.

Poulsen, N.E.; Gudmundsson, L.; Morten Hansen, J. \& Husfeldt, Y. 1990. Palynological preparation techniques, a new Macerationtank-method and other modifications. Geological Survey of Denmark, DGU series C, 10: 23 p.

Raine, J.I. \& Tremain, R. 1992. Apparatus for rapid sieving of palynological residues. New Zealand Geological Survey Report, PAL 151, 14 p.

Raistrick, A. 1934. The correlation of coal seams by microspore content. Part I. - The seams of Northumberland. Transactions of the Institution of Mining Engineers, 88:142-153.

Raistrick, A. \& Marshall, C.E. 1939. The nature and origin of coal and coal seams. The English Universities Press Limited, London, 282 p.

Raistrick, A. \& Simpson, J. 1933. The microspores of some Northumberland coals, and their use in the correlation of coalseams. Transactions of the Institution of Mining Engineers, 85:225-235.
Rawson, P. F.; Allen, P. \& Gale, A. 2001. The Chalk Group - a revised lithostratigraphy. Geoscientist, 11(1):21.

Richards, P.C.; Lott, G.K.; Johnson, H.; Knox, R.W.O'B. \& Riding, J.B. 1993. 3. Jurassic of the Central and Northern North Sea. In: R.W.O'B. Knox \& W.G. Cordey (eds.) Lithostratigraphic nomenclature of the UK North Sea, British Geological Survey, 224 p.

Riding, J.B. 2002a. A palynological investigation of the Upper Pliensbachian and Lower Toarcian strata at Brown's Hill Quarry, Holwell, Leicestershire. British Geological Survey, 14 p. (Internal Report IR/02/168).

Riding, J.B. 2002b. A palynological investigation of diamictons from the Britons Lane Borehole, north Norfolk. British Geological Survey, 15 p. (Internal Report, IR/02/191).

Riding, J.B. 2002c. A palynological investigation of a chalk-rich diamicton from Abbey Farm, near Hanworth, North Norfolk. British Geological Survey, 4 p. (Internal Report IR/02/174).

Riding, J.B. 2002d. A palynological study of some shallow cores from the Hebridean Slope. British Geological Survey, 8 p. (Internal Report, IR/02/038).

Riding, J.B.; Fedorova, V.A. \& Ilyina, V.I. 1999. Jurassic and lowermost Cretaceous dinoflagellate cyst biostratigraphy of the Russian Platform and northern Siberia, Russia. American Association of Stratigraphic Palynologists, 179 p. (Contributions Series 36).

Riding, J.B. \& Helby, R. 2001. Microplankton from the Mid Jurassic (late Callovian) Rigaudella aemula Zone in the Timor Sea, north-western Australia. Memoir of the Association of Australasian Palaeontologists, 24:65-110.

Riding, J.B. \& Ioannides, N.S. 1996. A review of Jurassic dinoflagellate cyst biostratigraphy and global provincialism. Bulletin de la Société Géologique de France, 167:3-14.

Riding, J.B. \& Thomas, J.E. 1988. Dinoflagellate cyst stratigraphy of the Kimmeridge Clay (Upper Jurassic) from the Dorset coast, southern England. Palynology, 12:65-88.

Riding, J.B. \& Thomas, J.E. 1992. Dinoflagellate cysts of the Jurassic System. In: A.J. Powell, (ed.) A stratigraphic index of dinoflagellate cysts, British Micropalaeontological Society Publications Series, Chapman and Hall, p. 7-97.

Riding, J.B.; Walton, W. \& Shaw, D. 1991. Toarcian to Bathonian (Jurassic) palynology of the Inner Hebrides, northwest Scotland. Palynology, 15:115-179.

Riley, L.A.; Roberts, M.J. \& Connell, E.R. 1989. The application of palynology in the interpretation of Brae Formation stratigraphy and reservoir geology in the South Brae Field area, British North Sea. In: J.D. Collinson (ed.) Correlation in hydrocarbon exploration, Graham and Trotman, p. 339356.

Robaszynski, F.; Bless, M.J.M.; Felder, P.J.; Foucher, J.-C.; Legoux, O.; Manivit, H.; Meessen, J.P.M.T. \& Van Der Tuuk, L.A. 1985. The Campanian-Maastrichtian boundary in the chalky facies close to the type-Maastrichtian area. Bulletin des Centres de Recherches Exploration-Production ElfAquitaine, 9:1-113.

Rowley, J.R. 1976. Dynamic changes in pollen wall morphology. In: I.K. Ferguson \& J. Muller (eds.) The evolutionary significance of the exine. Linnean Society Symposium Series, 1:39-66.

Rowley, J.R. 1990. The fundamental structure of the pollen exine. Plant Systematic Evolution, supplement 5:13-29. 
Rueger, B.F. 1986. Use of EDTA for palynomorph extraction from evaporites. Journal of Paleontology, 60:189-190.

Sarjeant, W.A.S. 1974. Fossil and living dinoflagellates. Academic Press, London, $182 \mathrm{p}$.

Sarmiento, R. 1957. Microfossil zonation of the Mancos group. American Association of Petroleum Geologists Bulletin, 41:1683-1693.

Savrda, C.E.; Krawinkel, H.; McCarthy, F.M.G.; McHugh, C.M.G.; Olson, H.C. \& Mountain, G. 2001. Ichnofabrics of a Pleistocene slope succession, New Jersey margin: relations to climate and sea-level dynamics. Palaeogeography, Palaeoclimatology, Palaeoecology, 171:41-61.

Schiøler, P. \& Wilson, G.J. 1993. Maastrichtian dinoflagellate zonation in the Dan Field, Danish North Sea. Review of Palaeobotany and Palynology, 78:321-351.

Schopf, J.M. 1960. Double cover-glass slides for plant microfossils. Micropaleontology, 6:237-240.

Schrank, E. 1988. Effects of chemical processing on the preservation of peridinioid dinoflagellates: a case from the Late Cretaceous of NE Africa. Review of Palaeobotany and Palynology, 56:123-140.

Shane, J.D. \& Clark, W.D. 1981. Recovering polymerized fossil palynomorph residues. Micropaleontology, 27:109-110.

Shaw, G. 1971. The chemistry of sporopollenin. In: J. Brooks, P.R. Grant, M. Muir, P. Van Gijzel \& G. Shaw (eds.) Sporopollenin. Proceedings of a Symposium held at the Geology Department, Imperial College, London, 23 $3^{\text {rd }}-25^{\text {th }}$ September, 1970. Academic Press, p. 305-350.

Shaw, G. \& Yeadon, A. 1964. Chemical studies on the constitution of some pollen and spore membranes. Grana Palynologica, 5:245-252.

Shephard-Thorn, E.R. 1988. Geology of the country around Ramsgate and Dover. London Memoir of the British Geological Survey, Sheets 274 and 279 (England and Wales). Her Majesty's Stationery Office, 49 p.

Shipp, D.J. 1999. Well-site biostratigraphy of Danish horizontal wells. In: R.W. Jones \& M.D. Simmons (eds.) Biostratigraphy in Production and Development Geology. Geological Society, p. 75-84 (Special Publication 152).

Simes, J. \& Wrenn, J. 1998. Palynologic processing in Antarctica. Terra Antarctica, 5:549-552.

Sittler, C. 1955. Méthodes et techniques physicochimiques de préparation des sédiments en vue de leur analyse pollinique. Revue de l'Institut Français du Pétrole et Annales des Combustibles Liquides, 10:103-114.

Slimani, H. 1994. Les dinokystes des Craies du Campanien au Danien a Halembaye, Turnhout (Belgique) et a Beutenaken (Pays-Bas). Mémoires pour servir à l'Explication des Cartes Géologiques et Minières de la Belgique - Toelichtende Verhandelingen voor de Geologische en Mijnkaarten van België, n. 37,173 p.

Slimani, H. 1996. Les dinokystes des Craies du Campanien-Danien a Halembaye et Turnhout (Belgique) et a Beutenaken (PaysBas). Supplement de systematique. Annales de la Société géologique de Belgique, 199:371-391.

Smith, A.V.H. \& Butterworth, M.A. 1967. Miospores in the coal seams of the Carboniferous of Great Britain. Special Papers in Palaeontology, 1:324 p.

Spielholtz, G.; Thomas, L.A. \& Diehl, H. 1962. Isolation of spores by wet oxidation. Micropaleontology, 8:109-110.
Srivastava, S.K. 1984. Jurassic spore-pollen assemblages from Normandy (France) and Germany. Geobios, 20:5-79.

Staplin, F.L.; Pocock, S.J.; Jansonius, J. \& Oliphant, E.M. 1960. Palynological techniques for sediments. Micropaleontology, 6:329-331

Traverse, A. 1978. 44. Palynological analysis of DSDP Leg 42B (1975) cores from the Black Sea. Initial Reports of the Deep Sea Drilling Project, 42(2):993-1015.

Traverse, A. 1988. Paleopalynology. Unwin Hyman, Boston, $600 \mathrm{p}$.

Traverse, A. 1990. The ravages of oxidation on pollen of Althaea rosea ("hollyhock"). Stuifmail, 8(1):12.

Traverse, A., Clisby, K.H. \& Foreman, F. 1961. Pollen in drillingmud "thinners," a source of palynological contamination. Micropaleontology, 7:375-377.

Tschudy, R.H. 1958. A modification of the Schulze digestion method of possible value in studying oxidized coals. Grana Palynologica, 1:34-38.

Tschudy, R.H. 1960. "Vibraflute". Micropaleontology, 6:325-326.

Tschudy, R.H. 1961. Palynomorphs as indicators of facies environments in Upper Cretaceous and Lower Tertiary strata, Colorado and Wyoming. In: Symposium on Late Cretaceous rocks, 16. Annual Field Conference, Guide Book, Wyoming Geological Association, p. 53-59.

Urban, J.B. 1961. Concentration of palynological fossils by heavyliquid flotation. Oklahoma Geology Notes, 21:191-193.

Van Der Kaars, W.A. \& Smit, J. 1985. A palynological field preparation technique. Pollen et Spores, 27:493-496.

Van Stuijvenberg, J. 1979. Geology of the Gurnigek area (Prealpes, Switzerland). Beiträge zur Geologischen Karte der Schweiz, n.s., 151:1-111.

Van Wazer, J.R. (ed.) 1958. Phosphorus and its compounds. Volume 1 - Chemistry. Interscience, New York, 56 p.

Vidal, G. 1988. A palynological preparation method. Palynology, 12:215-220.

Von Post, L. 1916. Om skogsträdpollen i sydsvenska torfmosselagerföljder (foredragsreferat). Geologiska Föreningens $i$ Stockholm Förhandlingar, 38:384-390.

Wall, D.; Dale, B.; Lohman, G.P. \& Smith, W.K. 1977. The environmental and climatic distribution of dinoflagellate cysts in modern marine sediments from regions in the north and south Atlantic Ocean and adjacent seas. Marine Micropaleontology, 2:121-200.

Wetzel, O. 1933. Die in organischer Substanz erhaltenen Mikrofossilien des baltischen Kreide-Feuersteins mit einem sedimentpetrographischen und stratigraphischen Anhang. Palaeontographica Abteilung A, 78:1-110.

Williams, G.; Watson, P.; Payne, S.N.J.; Dyer, R. \& Ewen, D.F. 2003. Non-acid wellsite palynology: widening opportunities. Palynology, 27:250 (abstract).

Williams, G.L. \& Downie, C. 1966a. The London Clay. In: R.J. Davey, C. Downie, W.A.S. Sarjeant \& G.L. Williams. Studies on Mesozoic and Cainozoic dinoflagellate cysts, Bulletin of the British Museum (Natural History) Geology, Supplement 3:20-27.

Williams, G.L. \& Downie, C. 1966b. IX. Wetzeliella from the London Clay. In: R.J. Davey, C. Downie, W.A.S. Sarjeant \& G.L. Williams (eds.) Studies on Mesozoic and Cainozoic dinoflagellate cysts, Bulletin of the British Museum (Natural History) Geology, Supplement 3:182-198. 
Williams, G.L. \& Downie, C. 1966c. XI. Further dinoflagellate cysts from the London Clay. In: R.J. Davey, C. Downie, W.A.S. Sarjeant \& G.L. Williams (eds.) Studies on Mesozoic and Cainozoic dinoflagellate cysts, Bulletin of the British Museum (Natural History) Geology, Supplement 3:215235.

Williams, G.L.; Lentin, J.K. \& Fensome, R.A. 1998. The Lentin and Williams index of fossil dinoflagellates 1998 edition. American Association of Stratigraphic Palynologists, 817 p. (Contributions Series 34).

Wilson, G.J. 1971a. A chemical method for the palynological processing of Chalk. Mercian Geologist, 4:29-36.

Wilson, G.J. 1971b. A method for the recovery of mounted palynological residues. Mercian Geologist, 4:139-141

Wilson, G.J. 1974. Upper Campanian and Maastrichtian dinoflagellate cysts from the Maastricht region and Denmark. Unpublished PhD thesis, University of Nottingham, Nottingham, $601 \mathrm{p}$.

Wilson, L.R. 1968. New water-miscible mountant for palynology. Micropaleontology, 14:247-248.

Wilson, L.R. \& Goodman, G.J. 1963. Techniques of Palynology - Part I. Collection and preparation of modern spores and pollen. Oklahoma Geology Notes, 23:167-171.

Wood, G.D.; Gabriel, A.M. \& Lawson, J.C. 1996. Palynological techniques - processing and microscopy. In: J. Jansonius \& D.C. McGregor (eds.) Palynology: principles and applications, American Association of Stratigraphic Palynologists Foundation, 1:29-50.
Wood, J.M. \& Segroves, K.L. 1963. Method for collecting coal and shale samples. Micropaleontology, 9:340.

Wrenn, J.H. 1998. The importance of palynologic sample processing to the oil industry. In: V.M. Bryant \& J.H. Wrenn (eds.) New developments in palynomorph sampling, extraction, and analysis, American Association of Stratigraphic Palynologists, p. 7-21 (Contributions Series, 33).

Zinsmeister, W.J.; Feldmann, R.M.; Woodburne, M.O. \& Elliot, D.H. 1989. Latest Cretaceous/earliest Tertiary transition on Seymour Island, Antarctica. Journal of Paleontology, 63:731738.

Zonneveld, K.A.F.; Versteegh, G.J.M. \& De Lange, G.J. 1997. Preservation of organic-walled dinoflagellate cysts in different oxygen regimes: a 10,000 year natural experiment. Marine Micropaleontology, 29:393-405.

Zonneveld, K.A.F.; Versteegh, G.J.M. \& De Lange, G.J. 2001. Palaeoproductivity and post-depositional aerobic organic matter decay reflected by dinoflagellate cyst assemblages of the Eastern Mediterranean S1 sapropel. Marine Geology, 172:181-195.

Received May, 2003; accepted January, 2004. 
APPENDIX 1. LISTING OF THE SAMPLES EXAMINED IN THIS STUDY

The 42 samples studied from seven localities in this work are listed here with all relevant geographical and geological information.

1. Brown's Hill Quarry, Holwell, Leicestershire (SK 742 235). Samples were collected by J. B. Riding on $12^{\text {th }}$ December 2001 ; the bed numbers are those of Hallam (1968). All three formations are within the Lias Group; MRF = Marlstone Rock Formation.

$\begin{array}{ll}\text { No. } & \text { Lithological Unit } \\ 1 & \text { Whitby Mudstone Fm. } \\ 2 & \text { Whitby Mudstone Fm. } \\ 3 & \text { Whitby Mudstone Fm. } \\ 4 & \text { Whitby Mudstone Fm. } \\ 5 & \text { Whitby Mudstone Fm. } \\ 6 & \text { Whitby Mudstone Fm. } \\ 7 & \text { Whitby Mudstone Fm. } \\ 8 & \text { Whitby Mudstone Fm. } \\ 9 & \text { Marlstone Rock Fm. } \\ 10 & \text { Marlstone Rock Fm. } \\ 11 & \text { Marlstone Rock Fm. } \\ 12 & \text { Marlstone Rock Fm. } \\ 13 & \text { Marlstone Rock Fm. } \\ 14 & \text { Dyrham Formation }\end{array}$

Zone/Bed No.
Falciferum/9
Falciferum/9
Falciferum/9
Falciferum/9
Falciferum/9
Falciferum/9
Falciferum/9
Falciferum/9
Tenuiserr./7
Tenuiserr./7
Tenuiserr./7
?Tenuiserr./7
Spinatum $/ 7$
Spinatum $/ 5$

Lithology
shale
shale
shale
clay
limestone
mudstone
mudstone
mudstone
limestone
limestone
limestone
limestone
limestone
sandstone

Sample position

$316 \mathrm{~cm}$ from top MRF $216 \mathrm{~cm}$ from top MRF $136 \mathrm{~cm}$ from top MRF $95 \mathrm{~cm}$ from top MRF $95 \mathrm{~cm}$ from top MRF $70 \mathrm{~cm}$ from top MRF $40 \mathrm{~cm}$ from top MRF $20 \mathrm{~cm}$ from top MRF Uppermost part of MRF $116 \mathrm{~cm}$ below top MRF $230 \mathrm{~cm}$ below top MRF $90 \mathrm{~cm}$ above base MRF Lowermost $0.75 \mathrm{~cm}$ MRF $20 \mathrm{~cm}$ below base MRF

2. Dover Harbour Borehole (P000), Kent (TR 3341 4138). Samples were collected by J. E. Kyffin-Hughes. All are from the Gault Formation (Middle and Upper Albian). The Lower Gault (Middle Albian) and the Upper Gault (Upper Albian) are informal lithostratigraphical subdivisions.

\begin{tabular}{|c|c|c|c|c|c|}
\hline No. & Lithostrat. & Bed No. & lithology & Zone & Depth (m) \\
\hline 15 & Upper Gault & Bed 6a & grey mudstone & Dispar & 108.00 \\
\hline 16 & Upper Gault & Bed X1 & grey mudstone & Inflatum & 112.00 \\
\hline 17 & Upper Gault & Bed X1 & grey mudstone & Inflatum & 116.00 \\
\hline 18 & Upper Gault & Bed X1 & grey mudstone & Inflatum & 120.00 \\
\hline 19 & Upper Gault & Bed X & grey mudstone & Inflatum & 124.00 \\
\hline 20 & Lower Gault & Bed V11 & grey mudstone & Lautus & 128.60 \\
\hline 21 & Lower Gault & Bed 111 & grey mudstone & Loricatus & $132.70-133.00$ \\
\hline 22 & Lower Gault & Bed 11 & grey mudstone & Loricatus & 136.70 \\
\hline 23 & Lower Gault & & grey mudstone & Dentatus & 140.00 \\
\hline 24 & Lower Gault & & dark grey mudstone & ?Dentatus & 144.00 \\
\hline
\end{tabular}

3. BGS Trunch Borehole, Norfolk, UK (TG 2933 3455). Samples were collected by J. E. Kyffin-Hughes and are from the White Chalk Subgroup. The sampled interval incorporates the Campanian-Maastrichtian transition. Samples 1 and 2 are soft, marly chalks from the Lower Maastrichtian (Lanceolata Zone). The remaining samples, 3-5, are from the massive white Paramoudra Chalk that is latest Campanian in age (Mucronata Zone). This borehole was drilled in order to give a reference section of the most complete Chalk Group development in the UK and discovered an especially well developed White Chalk Subgroup succession. A preliminary log was given by Gallois \& Morter in Institute of Geological Sciences (1976, pp. 8-10). The sample details here, however, are taken from the revised log (BGS, unpublished).

$\begin{array}{lclllr}\text { No. } & \text { BGS Reg. No. } & \text { Lithostrat. Unit } & \text { Zone } & \text { Substage } & \text { Depth (m) } \\ 25 & \text { MPA 50894 } & \text { Sidestrand Chalk } & \text { Lanceolata } & \text { L. Maastricht. } & 57.60 \\ 26 & \text { MPA 50895 } & \text { Sidestrand Chalk } & \text { Lanceolata } & \text { L. Maastricht. } & 60.14-60.50 \\ 27 & \text { MPA 50896 } & \text { Paramoudra Chalk } & \text { Mucronata } & \text { U. Campanian } & 67.51-71.32 \\ 28 & \text { MPA 50897 } & \text { Paramoudra Chalk } & \text { Mucronata } & \text { U. Campanian } & 80.40-80.60 \\ 29 & \text { MPA 50898 } & \text { Paramoudra Chalk } & \text { Mucronata } & \text { U. Campanian } & 81.00-81.20\end{array}$

4. Bodman Point, Seymour Island, Antarctica (64' 15' 24' S; 56 48' 67'W). Samples were collected by D. J. Cantrill and J. A. Crame (British Antarctic Survey) during the Austral summer of 2000/2001. All samples are from the López de Bertodano Formation (Marambio Group).

$\begin{array}{lccc}\text { No. } & \text { BAS Reg. Number } & \text { BGS Reg. Number } & \text { Height from base of section (m) } \\ 30 & \text { DJ.915.16 } & \text { MPA 49924 } & 90.00 \\ 31 & \text { DJ.915.15 } & \text { MPA 49923 } & 84.00 \\ 32 & \text { DJ.915.11 } & \text { MPA 49919 } & 60.00 \\ 33 & \text { DJ.915.8 } & \text { MPA 49916 } & 42.00 \\ 34 & \text { DJ.915.6 } & \text { MPA 49914 } & 30.00 \\ 35 & \text { DJ.915.2 } & \text { MPA 49910 } & 6.00\end{array}$


5. Commonwealth Games Stadium Site, Manchester, Lancashire, UK (SJ 387100 398500). These samples are of brown, clay- and erratic-rich Devensian (Upper Pleistocene) Till.

\section{Sample Number}

36

37

\author{
BGS Registration Number \\ MPA 51062 \\ MPA 51063
}
Depth (m)
1.00
4.00

6. BGS Britons Lane Borehole, North Norfolk, UK (TG 168 415). This borehole was drilled at Britons Lane Quarry, Beeston Regis, near Sheringham and cored grey, brown and highly chalky diamicton units to $32.00 \mathrm{~m}$ (Riding, 2002b). Both samples here are highly chalky diamictons.

\section{Sample Number}

38

39

\author{
BGS Registration Number \\ MPA 50994 \\ MPA 50997
}

\section{Depth (m) \\ 16.90-17.00 \\ 22.50-22.95}

7. BGS Offshore Borehole 56-10/249 CS. This shallow offshore is located west of the Hebrides at $56^{\circ} 14.53^{\prime} \mathrm{N} 009^{\circ} 13.95^{\prime} \mathrm{W}$.

$\begin{array}{lccc}\text { Number } & \text { BGS Registration No. } & \text { Depth }(\mathbf{m}) & \text { Lithology } \\ 40 & \text { MPA } 50819 & 0.50-0.53 & \text { dark brown/black clay } \\ 41 & \text { MPA } 50820 & 1.80-1.83 & \text { dark brown clay } \\ 42 & \text { MPA } 50821 & 2.38-2.41 & \text { brown/black clay }\end{array}$

\section{APPENDIX 2. FULL DESCRIPTION OF THE PALYNOLOGICAL PROCESSING TECHNIQUE USING SODIUM} HEXAMETAPHOSPHATE.

This method was developed iteratively in a working palynological laboratory (see also Figure 1).

1. Place approximately $100 \mathrm{~g}$ of cleaned rock sample, which has been crushed to $c$. pea-sized fragments, into a large glass/pyrex beaker.

2. Add c. $400 \mathrm{ml}$ of hot/warm distilled/pure water and c.1\% of strong detergent (e.g. Teepol), stir thoroughly and leave overnight.

3. Place the beaker on a magnetic hot plate set at a moderate heat level with a plastic-coated magnetic stirrer and agitate the mixture thoroughly.

4. Add c. $40 \mathrm{ml}$ of sodium hexametaphosphate $\left[\left(\mathrm{NaPO}_{3}\right)_{6}\right]$ flakes to the sample vessel on the stirred hotplate. The substance mass in a specific volume of flakes is clearly variable, depending upon factors such as packing and the size/shape of the flakes. However, within reasonable limits, the amount of $\left(\mathrm{NaPO}_{3}\right)_{6}$ is not critical in this technique.

5. Stir the mixture magnetically for $c$. 15-20 minutes.

6. Sieve the $>500 \mu \mathrm{m}$ fraction off and retain.

7. Sieve the sample mixture at $10 \mu \mathrm{m}$. It is anticipated that the $<10 \mu \mathrm{m}$ fraction will dominantly be deflocculated clay particles; these may be retained in order to determine if palynomorphs are present in this fraction or discarded. It is unlikely, however, that significant numbers of palynomorphs will be present in the $<10 \mu \mathrm{m}$ fraction. Ensure that all the $\left(\mathrm{NaPO}_{3}\right)_{6}$ is washed out of the residue and retain the residue.

8. Treat the $>500 \mu \mathrm{m}$ fraction with hydrogen peroxide $\left(\mathrm{H}_{2} \mathrm{O}_{2}\right)$ for $c$. $15-20$ minutes in order to determine if these rock fragments break down.

9. Sieve this mixture at $10 \mu \mathrm{m}$ to remove the 'fines' and retain the residue. Ensure that all of the $\mathrm{H}_{2} \mathrm{O}_{2}$ is washed out of the residue.

10. Should any of the $>500 \mu \mathrm{m}$ fraction remain, repeat steps 8 and 9 repeatedly until all the rock sample has broken down using $\mathrm{H}_{2} \mathrm{O}_{2}$.

11. Mix together the post- $\left(\mathrm{NaPO}_{3}\right)_{6}$ and $\mathrm{H}_{2} \mathrm{O}_{2}$ residues. Should significant levels of resistant mineral grains be present, the majority can be removed by 'swirling' the residue in a large watch glass. This step should only be performed carefully because there is a chance that palynomorphs can become physically incorporated into the mineral fraction.

12. Centrifuge the residue with heavy liquid to separate any remaining resistant mineral grains and the organic fraction. This type of heavy liquid separation with c. 2.0 specific gravity zinc bromide is part of the normal palynological preparatory procedure. Ensure that all remaining zinc bromide is washed out of the residue.

13. Mount the concentrated organic residue, after appropriate staining if required, on microscope slides.

\section{APPENDIX 3. LISTING OF PALYNOMORPH SPECIES.}

All validly published palynomorph taxa that are mentioned in this work are listed here. A full bibliography on dinoflagellate c yst taxonomy was given by Williams et al. (1998).

Dinoflagellate cysts

Achomosphaera andalousiensis Jan du Chêne 1977

Alisocysta circumtabulata (Drugg 1967) Stover \& Evitt 1978

Alisogymnium euclaense (Cookson \& Eisenack 1970) Lentin \& Vozzhennikova 1990

Alterbidinium acutulum (Wilson 1967) Lentin \& Williams 1985 
Bitectatodinium tepikiense Wilson 1973

Brigantedinium simplex Wall 1965 ex Lentin \& Williams 1993

Cannosphaeropsis utinensis O. Wetzel 1933

Chlamydophorella nyei Cookson \& Eisenack 1958

Circulodinium distinctum (Deflandre \& Cookson 1955) Jansonius 1986

Cladopyxidium paucireticulatum Slimani 1994

Coronifera oceanica Cookson \& Eisenack 1958

Cribroperidinium? edwardsii (Cookson \& Eisenack 1958) Davey 1969

Cribroperidinium sepimentum Neale \& Sarjeant 1962

Ctenidodinium combazii Dupin 1968

Cyclonephelium compactum Deflandre \& Cookson 1955

Exochosphaeridium bifidum (Clarke \& Verdier 1967) Clarke et al. 1968

Exochosphaeridium phragmites Davey et al. 1966

Florentinia mantellii (Davey \& Williams 1966) Davey \& Verdier 1973

Fromea amphora Cookson \& Eisenack 1958

Gillinia hymenophora Cookson \& Eisenack 1960

Hystrichosphaeridium tubiferum (Ehrenberg 1838) Deflandre 1937

Hystrichosphaeropsis quasicribrata (O. Wetzel 1961) Gocht 1976

Isabelidinium cooksoniae (Alberti 1959) Lentin \& Williams 1977

Isabelidinium pellucidum (Deflandre \& Cookson 1955) Lentin \& Williams 1977

Mancodinium semitabulatum Morgenroth 1970

Manumiella seelandica (Lange 1969) Bujak \& Davies 1983

Manumiella seymourensis Askin 1999

Membranilarnacia angustivela (Deflandre \& Cookson 1955) McMinn 1988

Microdinium bensonii Slimani 1994

Microdinium granocarinatum (Below 1987) Lentin \& Williams 1989

Nannoceratopsis deflandrei Evitt 1961 subsp. deflandrei (autonym)

Nannoceratopsis deflandrei Evitt 1961 subsp. senex (van Helden 1977) Ilyina in Ilyina et al. 1994

Nannoceratopsis gracilis Alberti 1961

Nannoceratopsis pellucida Deflandre 1939

Neoeurysphaeridium glabrum Slimani 1994

Neonorthidium perforatum Marheinecke 1992

Octodinium askiniae Wrenn \& Hart 1988

Odontochitina operculata (O. Wetzel 1933) Deflandre \& Cookson 1955

Operculodinium centrocarpum (Deflandre \& Cookson 1955) Wall 1967

Ovoidinium scabrosum (Cookson \& Hughes 1964) Davey 1970

Palaeoperidinium pyrophorum (Ehrenberg 1838 ex O. Wetzel 1933) Sarjeant 1967

Palaeotetradinium maastrichtiense Herngreen et al. 1986

Protoellipsodinium spinocristatum Davey \& Verdier 1971

Rottnestia wetzelii (Deflandre 1937) Slimani 1994

Scriniocassis weberi Gocht 1964

Scriniodinium campanula Gocht 1959

Spiniferites ramosus (Ehrenberg 1838) Mantell 1854

Spongodinium delitiense (Ehrenberg 1838) Deflandre 1936

Stephodinium coronatum Deflandre 1936

Subtilisphaera perlucida (Alberti 1959) Jain \& Millepied 1973

Tabularium senarium Dodekova 1990

Wilsonisphaera petila (Corradini 1973) Slimani 1994

Wrevittia cassidata (Eisenack \& Cookson 1960) Helenes \& Lucas-Clark 1997

Xenascus ceratioides (Deflandre 1937) Lentin \& Williams 1973

Xenascus "wetzelii" of Slimani (1996)

Xiphophoridium alatum (Cookson \& Eisenack 1962) Sarjeant 1966

Miscellaneous microplankton

Botryococcus braunii Kützing 1849

Halosphaeropsis liassica Mädler 1963

Tasmanites newtoni Wall 1965 


\section{Spores and pollen}

Ceratosporites equalis Cookson \& Dettmann 1958

Cerebropollenites macroverrucosus (Thiergart 1949) Schulz 1967

Cibotiumspora juriensis (Balme 1957) Filatoff 1975

Cirratriradites saturni (Ibrahim 1932) Schopf et al. 1944

Classopollis classoides (Pflug 1953) Pocock \& Jansonius 1961

Classopollis meyeriana Klaus 1960

Concavissimisporites verrucosus Delcourt \& Sprumont 1955

Coronatispora valdensis (Couper 1958) Dettmann 1963

Crassispora kosankei (Potonié and Kremp 1955) Bharadwaj 1957

Cristatisporites indignabundus (Loose in Potonié et al. 1932) Staplin \& Jansonius 1964

Cyathidites australis Couper 1953

Dictyotriletes bireticulatus (Ibrahim in Potonié et al. 1932) Smith \& Butterworth 1967

Endosporites globiformis (Ibrahim in Potonié et al. 1932) Schopf et al. 1944

Ischyosporites variegatus (Couper 1958) Schulz 1967

Lycospora pusilla (Ibrahim in Potonié et al. 1932) Schopf et al. 1944

Microcachryidites antarcticus Cookson 1947

Osmundacidites wellmanii Couper 1958

Peninsulapollis gillii (Cookson 1957) Dettmann \& Jarzen 1988

Peninsulapollis truswelliae Dettmann \& Jarzen 1988

Perinopollenites elatoides Couper 1958

Perotriletes majus (Cookson \& Dettmann 1958) Evans 1970

Phyllocladidites mawsonii Cookson 1947

Polycolpites langstonii Stover in Stover \& Partridge 1973

Radiizonates aligerens (Knox 1950) Staplin \& Jansonius 1964

Raistrickia fulva Artüz 1957

Retitriletes austroclavatidites (Cookson 1953) Döring et al. 1963

Tripartites vetustus Schemel 1950 